\title{
Towards liveable volcanic cities: A look at the governance of lahars in Yogyakarta, Indonesia, and Latacunga, Ecuador
}

\author{
Vicky Ariyanti $^{\mathrm{a}, \mathrm{b}, *}$, Tasneim Gaafar ${ }^{\mathrm{a}}$, Safira De La Sala ${ }^{\mathrm{a}}$, Jurian Edelenbos ${ }^{\mathrm{a}}$, Peter Scholten ${ }^{\mathrm{a}}$

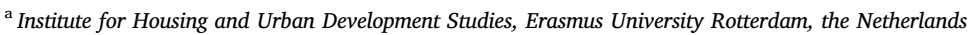 \\ ${ }^{\mathrm{b}}$ LPDP, Indonesia
}

\section{A R T I C L E I N F O}

\section{Keywords:}

Volcanic river basin planning

Lahar risks management

Mount Merapi

Mount Cotopaxi

Build back better

\begin{abstract}
A B S T R A C T
The physical and governance challenges posed by urban planning and integrated water resources management (IWRM) are gaining momentum worldwide. Yet, the governance of Volcanic River Basins (VRB) remains vastly unexplored. There are at least 500 active volcanoes worldwide, with 600 million people living near them. Through a multiple-case study methodology, we aim to contribute to the understanding of how lahar risks management is being conducted in two distinct urbanized volcanic river basins: Yogyakarta in Indonesia, and Latacunga in Ecuador. Both are located in the "ring of fire" with recent eruption threats in the last decade. The two cases were conducted independently, both triangulated by international and national literature reviews, policy analysis, and in-depth interviews. The Indonesian case study focuses on the governance intricacies for water and disaster management after 2010 eruption during pre, onset, and post-eruption. The Ecuadorian case study looks at risk governance from the perspective of households after a volcanic eruption in 2015, highlighting how bottom-up risk management strategies interact with top-down governance policies. Based on both case studies, a synthesis framework for Volcanic River Basin Management (VRBM) is formulated. This framework can be used as the way forward to analyze disaster and resources management in urbanized volcanic areas.
\end{abstract}

\section{Introduction}

As cities continue to grow at unprecedented rates around the globe, they are faced with man-made and natural hazards imposing challenges critical to their existence. Volcanoes present a source of these hazards as they presume a major threat to millions of lives; however, they provide resource endowments that continue to attract agglomerations of populations to high-risk areas (Chester et al., 2002; Engerman \& Sokoloff, 2002). In addition to creating some of the most fertile soils on earth volcanoes present a rich source of tourism and provide various minerals for mining (Stone et al., 2014).

Evacuation and resettlement efforts from areas at high volcanic risk have hence failed, as residents perceive the benefits of remaining in areas prone to volcanic disaster surpass the costs (Sagala et al., 2009). This risk is increased by the fact that volcanoes can remain dormant for long periods and reactivate gradually, providing, in most cases, enough warning before devastating eruptions (Favereau et al., 2018).

Volcanic activity can range from airborne ash and gases to magma and pyroclastic flows. Lahars are one of these hazards, which take place in the physical context of land and can lead to the devastation of people and cities. Originally an Indonesian term, the word "lahar" is used to describe flows of debris, transition, or hyper-concentrated flows that originate at the volcano. Lahars are characterized by a high liquid percentage that makes them flow to areas far from the source. Their destructive power is increased by their speed, reach, and the rock fragments they carry (Vallance, 2000).

Lahar flows can be highly destructive, causing damage to anything in their path. They can occur during a volcanic eruption due to pyroclastic flows melting the glacier top, or by volcanic debris mobilized by rain. The latter occurrence is more dangerous due to its unpredictability (Pierson et al., 2014).

Managing lahar risk imposes a challenge to local governments as they are characterized in many cases by a low probability and extremely high impact if they occur, as geological times are quite distinct from the usual human lifespan. And yet, with increasing knowledge on climate change, there is the urgency to raise awareness and discuss the topic, particularly on the lahars fostered by melting glacier tops and change in rainfall patterns.

Therefore, in this article, we aim to contribute to the understanding of what constitutes lahar risk management (LRM) and how it is implemented in the context of urban settings in different volcanic river basins (VRB). The complexity of the topic is tackled through the

\footnotetext{
* Corresponding author at: Institute for Housing and Urban Development Studies, Erasmus University Rotterdam, the Netherlands

E-mail addresses: ariyanti@ihs.nl (V. Ariyanti), safiradelasala@gmail.com (S. De La Sala).
} 
analysis of two distinct case studies: Mt. Merapi, in the Island of Java (Indonesia), and Mt. Cotopaxi, in Latacunga (Ecuador).

Lahar risk management (LRM) and volcanic river basin (VRB) overlap in the pre-existing urban planning and integrated water resources management (IWRM) approach implementation. The overlaps are located as all of them occupy the same space with conflicting interests and prioritizations of land-use, which are sometimes against the hazard zone delineations. Such conflicts can be found in many volcanic river basins around the world (Cashman \& Giordano, 2008; Delcamp et al., 2016; Dorava \& Meyer, 1994).

Mt. Merapi in Java, Indonesia, is one of the most active volcanoes in the world. In 2010, a mortal eruption took place with a four Volcanic Explosivity Index (VEI) out of a scale of eight, marking a-100 years periodical cycle and located near an urbanized area of around two million people in Yogyakarta-Sleman-Bantul agglomeration (Provinsi \& Yogyakarta, 2018). The event severely impacted the region leaving almost 400 deaths, IDR 3.56 Trillions of damage in infrastructure, including roads, weirs, dams, irrigation channels, and houses (Widayani, 2011).

The second case study looks at Mt. Cotopaxi, Ecuador, and its neighbouring city Latacunga. Cotopaxi's last major eruption took place in 1887 marking a 100-year cycle with a VEI of 4. Damage from the event was estimated to resemble the Nevado Del Ruiz volcanic disaster that killed over 23,000 people in 1885 (Mothes et al., 2017; Pierson et al., 2014; Vallance, 2000). Since then it had remained quiet with relatively no activity until a small eruption in 2015 of less than 2 VEI caused major havoc in the city and led to policy changes that placed hundreds of homes in the high-risk area.

Therefore, we can notice the complexity this environmental hazard puts into socio-spatial settings. It also made the cases extremely relevant to study the interrelations of lahar management (LRM) and integrated water resources management (IWRM) in urban scenarios, increasing the relevance for a multi-case analysis. In this paper, we approach the governance and authority structures in place, as well as its constraints, to tackle volcanic river basins planning and management during the three phases of the eruption (pre, onset, and post) in the cities of Yogyakarta and Latacunga. Given that both cases are located in urbanized volcanic river basins, but differ on the ways lahar risk management are addressed. Each case will present how the concepts of disaster risk management and integrated water resources management are implemented in the urban planning context, aiming to shed light on how other Volcanic Cities can be safer and successful.

\section{Literature review}

To understand the context in which Lahar Risk Management (LRM) develops, it is important to bear in mind three interconnected elements: disaster risk reduction framework, integrated water resources management, and lahar risk management in the context of urban planning. Hence, each concept is explained, and the interconnection of these concepts is proposed in this literature review.

\subsection{Disaster risk reduction framework}

Disasters occur as a result of unprepared cities and in many cases, unplanned development. They are a combination of natural hazards and conditions of vulnerability and insufficient capacity or measures to reduce the negative consequences of risk. Disasters disrupt the functioning of communities causing losses in human lives and assets, which exceed the affected society's capacity to adapt, using their means (Ahrens \& Rudolph, 2006).

The Disaster Risk Reduction (DRR) framework aims to reduce the expected loss statically from a particular type of risk. This is done by reducing the likelihood of hazards, reducing the expected loss, or both, with prerequisites of clear understanding of the cultural and organizational character in society and active involvement of NGO and local communities (Wisner et al., 2004). The current UN Sendai Framework for DRR 2015-2030 (UNISDR, 2015) aims to guide multi-hazard management of DRR at all levels across in all sectors, utilizing priorities for (1) understanding risks, (2) strengthening disaster risks governance, (3) investing in DRR for resilience, and (4) enhancing preparedness to build back better.

Current research in Disaster Risk Management (DRM) is moving towards a risk governance approach (Ahrens \& Rudolph, 2006). This emerging field draws from complexity theory (Bettencourt, 2013) and network governance to analyze the institutions, actors, and networks involved in managing disaster risk and the formulation of policy through this complex nexus. The system of risk governance identifies the institutional arrangements that determine the roles and responsibilities of these actors and their relationships, the political culture and coordinating mechanisms, and the different perceptions of risk (Wilkinson, 2013). Generally, the DRR framework is divided into the phases of disaster: pre, onset, and post-disaster (UNISDR, 2015). The activities in a VRB are also based on these phases.

\subsection{Lahars risks management}

Managing lahar risk needs to recognize the interacting risk and benefits of living near water and the complex actors involved in this association. This direction is supported by researchers such as Kelman and Mather (2008) who suggest the implementation and understanding of volcanic benefits within the existing risk management frameworks. Research undertaken in Arequipa-Peru concluded that a multidisciplinary approach is essential to evaluate losses and gain a more holistic vision of the problem and solution (Thouret et al., 2013).

Several attempts were made to categorize strategies used to mitigate lahar risk (Kelman \& Mather, 2008; Pierson et al., 2014). While some researchers recognize the role of multiple actors in risk management, and the importance of including communities and scientists for successful implementation (Donovan \& Oppenheimer, 2014; Eiser et al., 2012; Pierson et al., 2014) the majority of strategies found in the literature are implemented primarily as top-down approaches. Pierson et al. (2014) classify these strategies into four categories:

1. Avoidance of hazard through land-use planning. Often this includes land-use zoning regulations or development of parks, disincentive of occupation in hazard zones, and providing public education on the risk and hazards.

2. Modification of lahar. This includes the use of engineered protection structures, such as dikes in the case of Mt. Pinatubo in the Philippines, Sabo, or checks dams for Japanese volcanoes.

3. Early warning systems. These take multiple shapes and provide a point of collaboration between formal and informal institutions. An example is the vigias (look-outs) in Ecuador who are the cooperation of multiple actors and institutions and exemplify an integrated system of monitoring and warning (Stone et al., 2014).

4. Response to recovery from lahars after they occur. This approach relies on the effectiveness of immediate response as well as longterm recovery.

"Rain lahars" are the most common feature of volcanoes in the world, as $46 \%$ or about 400 active volcanoes are located in the tropical region. However, they are poorly documented, as most occur in developing countries where not many trained scientists can be found (Rodolfo, 1991). Examples from Japan, the United States, New Zealand and the Philippines (Chanson, 2004; Keys \& Green, 2008; Major et al., 2000; Pierson et al., 2014; Trenberth \& Dai, 2007; Wood \& Soulard, 2009) are compared to present planning priorities of lahar management strategies. These examples use different approaches; Japan uses lahar infrastructures, such as Sabo dams, delineation of hazard zones, satellite monitoring, and early warning system (EWS) to evade from lahar risk (Chanson, 2004). Meanwhile, the United States prioritizes satellite 
monitoring and lahar infrastructure, such as sediment retention dam (SRD) at Mt. St. Helens, located in the State of Washington (Major et al., 2000). Both New Zealand and the Philippines do not use lahar infrastructures but depend on the compliance of hazard zone delineations (Gaillard, 2008; Keys \& Green, 2008). These examples highlight that compared to others, Japan uses the widest range of risk management strategies. It is hence considered the most advanced in lahar risk management making it a role model for countries with volcanoes in managing lahar risk.

\subsection{Integrated water resources management and lahars}

Water in the volcanic river basin has a significant role in the eruption process, as volcanoes act as water storage (Delcamp et al., 2016). The integrated water resources management (IWRM) approach addresses water-related hazards, such as flood, drought, and landslide, but does not include lahars (Global Water Partnership, 2000; Parry et al., 2007; Solanes \& Gonzales-Villarreal, 1999; Viviroli et al., 2011; Yusuf \& Francisco, 2009). This gap of knowledge is what we try to address.

Governance of lahar risks draws from an integrated water management approach and integrated volcanic risk management. This is derived by the fact that lahars share flooding characteristics such as a high saturation of liquid and their movement along water channels. Therefore, strategies targeting areas around riverbanks need to manage the exposure to lahar risk while balancing water management issues (Kelman \& Mather, 2008; Thouret et al., 2013). Water management conversely is shifting towards more integrated approaches to avoid conflict between diverse uses of water through improved coordination between actors (Rijke et al., 2012). This concept of integrated water management arose due to an increased awareness that nature is uncontrollable and new and innovative solutions are needed to manage water in cities. Such an approach transcends various temporal and governmental scales to balance short- and long-term objectives, anticipate future changes, and work towards a unified vision (Rijke et al., 2012).

Considering the aspects discussed above, Mitchell et al. (2015) identify planning and control of land-use as two measures of land governance that are necessary to achieve sustainable and resilient urban development; the form of development that is key for cities to withstand disasters. Nonetheless, mainstreaming these measures in local governance can be challenging; as rapid urbanization increases conventional -use planning becomes ineffective in controlling urban expansion extending to hazard areas (Mitchell et al., 2015).

Given the discussed above, Table 1, below, details the multiple dimensions involved in integrated water resource management, that connects natural, spatial, temporal, and human dimensions and its interconnected sub-dimensions to urban planning and management.

\section{Methods}

To enrich the understanding of how lahar risk management is developing in different urbanized volcanic river basins, we selected multiple case-study methods, combining exploratory and inductive strategies.

The selected case-studies are both located on the so-called "ring of fire", a tectonic region in the Pacific that hosts about $90 \%$ of the global earthquakes: Java (Indonesia) and Latacunga (Ecuador) as pictured in Fig. 1. We explore the complexity of the topic - and the way forward through their different planning traditions, perceptions of risk, governance structure, and household-based challenges. As Alterman (2011) poses it, land use laws, as well as property laws, tend to have long-term local tradition and nationally unique jurisprudence. Intertwined with environmental regulations, still very little international intervention are seen in concrete, despite initiatives such as the Sendai Framework for Disaster Risk Reduction. Therefore, comparative local analyses are of extreme relevance to understand the unfolding interactions and development - on the ground - of disaster resilience policies.

Our first case study is Mt. Merapi in the Island of Java, Indonesia, with its adjacent Opak Sub-basin. The data collection was done following a PhD trajectory of 2015-2019, where two months of fieldwork in 2016, as complete fieldwork was done in the dry season (August-September), and one month in 2018 (January) in the rainy season for validity check.

Mt. Merapi was chosen as a case study because it is one of the most active volcanoes in the world. It erupted in 2010 with 4 Volcanic Explosivity Index (VEI) out of 8 scales, marking a 100 years periodical cycle. Its location near an urbanized area of around two million inhabitants in the Yogyakarta-Sleman-Bantul agglomeration (Provinsi \& Yogyakarta, 2018), as explained in the introduction will be further developed in the next section.

We used qualitative methods to understand the relationships formed and the strengths and pitfalls in this search for resilience. The methods are triangulated by local and international literature review, policy and regulation analysis and 57 open-ended and in-depth interviews to relevant organizations such as the river basin organization, the disaster management agencies, the center for Mt. Merapi volcano, and community-based organizations (CBOs). The subcases as representatives of the volcanic river basin were chosen based on urbanized areas in the basin, one located upstream, one located midstream, and one located downstream. The primary and secondary data collected was analyzed using the Atlas.ti software (Friese, 2019; Hwang, 2008; Muhr, 1991) as a means to help structure the data into clusters of codes and develop it into relationships.

In the second case study, we look at lahar risk governance from a combination of top-down and bottom-up approaches. This case was chosen due to its recent eruption in 2015 and the threat of mount Cotopaxi as one of the most dangerous in the region and the most dangerous in Ecuador (Mothes et al., 2017). The data collection was done for a Master's thesis trajectory in the academic year of 2018-2019. With a history of dramatic eruptions, Mt. Cotopaxi is one of the most active volcanoes in Ecuador, with more than 50 eruptions since 1738 (Mothes et al., 2017). Located $37 \mathrm{~km}$ from Mt. Cotopaxi, the City of Latacunga suffered immense destruction from lahar floods caused by its last massive eruption in 1877. More recently, in 2015, a small eruption tested the city's preparedness but also gave the citizens valuable experience on what issues they might face in case of a bigger event.

Mixed-methods of quantitative and qualitative analysis were used to understand how citizens perceive lahar risk and to cover a wider range of respondents, during one month of fieldwork in June and July 2019. A total of 200 surveys were distributed within different risk zones where areas were selected according to the land use and management plan made by the local government. The plan categorizes areas around the rivers into safe, low risk, medium risk, and high-risk zones. A stratified sample was made by selecting five neighborhoods that are primarily residential and include large areas at risk. The questionnaires were distributed house to house by students who interviewed the respondents and uploaded the data to Qualtrics; the data analysis was undertaken using SPSS. Semi-structured interviews and secondary data were used to understand top-down risk governance in the city and to gain in-depth insights into the perspectives of households. A total of fourteen interviews were undertaken, including two purposely selected households in different risk zones and one community leader. Other interviews were done with local NGOs working with communities, government officials, and scientists from the Institute responsible for monitoring seismic activity in Ecuador: The Instituto Geofísico EPN (IG EPN). The secondary data included reviewed the land use and evacuation plans.

The two cases follow different approaches in compiling the data needed for this paper. Still they both contend with the growing environmental risks, awareness, and knowledge that cannot remain domestically insulated, even where specific legislation and governance 
Table 1

Details of IWRM dimensions (developed by the author, based on Jaspers, 2003; Marso, 2013; Graefe, 2011; Molle, 2009; Ndirangu, Kabubi, \& Dulo, 2009; Medema, McIntosh, \& Jeffrey, 2008; Savenije \& Zaag, 2008; Gleick, 2003; Lavigne \& Thouret, 2003; van Hofwegen \& Jaspers, 1999; and White, 1963).

\begin{tabular}{|c|c|c|}
\hline IWRM dimensions & Definitions & Sub-dimensions \\
\hline Natural dimension & Interrelated different types of resources and processes in water resources & $\begin{array}{l}\text { The interrelatedness of resources: } \\
\text { - Atmospheric conditions } \\
\text { - Water flows } \\
\text { - Land } \\
\text { The interrelation of natural processes: } \\
\text { - Hydro-meteorological: atmosphere-water flows } \\
\text { - Hydro-geological: water flows-land } \\
\text { Linking of hydro-geomorphological characteristics: } \\
\text { - Upstream } \\
\text { - Downstream }\end{array}$ \\
\hline Spatial dimension & $\begin{array}{l}\text { Linking of different scales, functions, and interconnection of hydro-geomorphological } \\
\text { conditions }\end{array}$ & $\begin{array}{l}\text { Linking of scales: } \\
\text { - Watershed } \\
\text { - River basin } \\
\text { - Inter-basin } \\
\text { Linking of functions: } \\
\text { - Land use } \\
\text { - Administrative delineation }\end{array}$ \\
\hline Temporal dimension & The holistic interrelation of time-related functions of water resources & $\begin{array}{l}\text { The interrelation of natural rhythms: } \\
\text { - Annual hydrological cycle } \\
\text { - Seasonal pattern } \\
\text { The interrelation to social pace: } \\
\text { - Water balance: supply-demand } \\
\text { - Term plan }\end{array}$ \\
\hline Human dimension & $\begin{array}{l}\text { The interrelatedness of all water users with their economic interests and organizational } \\
\text { relationship }\end{array}$ & $\begin{array}{l}\text { The interrelatedness of the leader: } \\
\text { - Person/organization/agency } \\
\text { - Integrating socio-economy-ecology benefits (multi- } \\
\text { oriented) } \\
\text { The interrelatedness of the norm (connective capacity): } \\
\text { - Analysis of decision making } \\
\text { - Fostering cooperation } \\
\text { - Inter-organizational collaboration }\end{array}$ \\
\hline
\end{tabular}

structures are concerned. The research adopts multiple case-study methods for the analysis of the governance of lahar management. Such a perspective is necessary if countries (and cities) are to learn from each other and push the knowledge frontier significantly forward, out of the "national boxes."

\section{Results}

\subsection{Case-study 1: Yogyakarta, Indonesia and Mt. Merapi}

Java is the most urbanized island in Indonesia and located in the southern part of the archipelago bordering the vast Indian Ocean to Australia. Indonesia is home to 127 active volcanoes, of which $30 \%$ are located in Java (Permen ESDM No.15/2011 on Mitigation Guidelines in Volcano, Land Movement, Earthquake, and Tsunami Hazards. 2011). Java's land is highly fertile due to the volcanic processes, which contribute to the flourishing of the agricultural industry.

The Yogyakarta Special Region has had a unique form of government, a Sultanate since the 1700 s and older kingdoms before that. Throughout the history of the Kingdoms that reigned on this part of Java Island, there was at least a massive eruption every 700 years (Schlehe, 1996). After each massive eruption, the area found a new Kingdom. Nevertheless, the Mt. Merapi's history of eruptions is more prolonged than human history; it has 10,000 years of volcanic eruptions (Newhall et al., 2000).

Disaster Management In Indonesia is recognized as a three phases process: pre, onset, and post-disaster (Fig. 2). For the 2010 Merapi eruption, the pre-eruption phase was anytime before the 2010 eruption, the eruption onset was during the eruption condition in November 2010, and post-eruption is directly after the eruption up to the next four years (Merapi's eruption cycle). The roles of stakeholders during each eruption phase are generally identified in the disaster management law, with the enforcement being of the authority of the regional government. In this context, the disaster management agency holds a commanding role only during the eruption onset.

In the case of Mt. Merapi and the urbanized area of Yogyakarta, the modern-day inhabitants have known their risks of living with an active volcano. Before the 2010 eruption, the Mt. Merapi erupted every four years; eruptions were characterized by the pyroclastic flow up to $4 \mathrm{~km}$ radius, new dome emergence and collapse, and lahar flow during the rainy season (De Bélizal et al., 2013; Lavigne \& Thouret, 2003).

The locations of the sub-cases are chosen based on the worst impacts for each respective location in the upstream, midstream, and downstream of Opak Sub-basin. These locations are signalled with the red dots in Fig. 4, ahead. The three cities are located in the agglomeration of Yogyakarta, known as Kartamantul. The selected cases are SlemanSubcase 1 Argomulyo in the upstream, Yogyakarta-Subcase 2 Gowongan in the mid-stream, Bantul - Subcase 3 Kebon Agung in the downstream.

\subsubsection{Pre-eruption}

The volcanology department at the Ministry of Energy and Mineral 


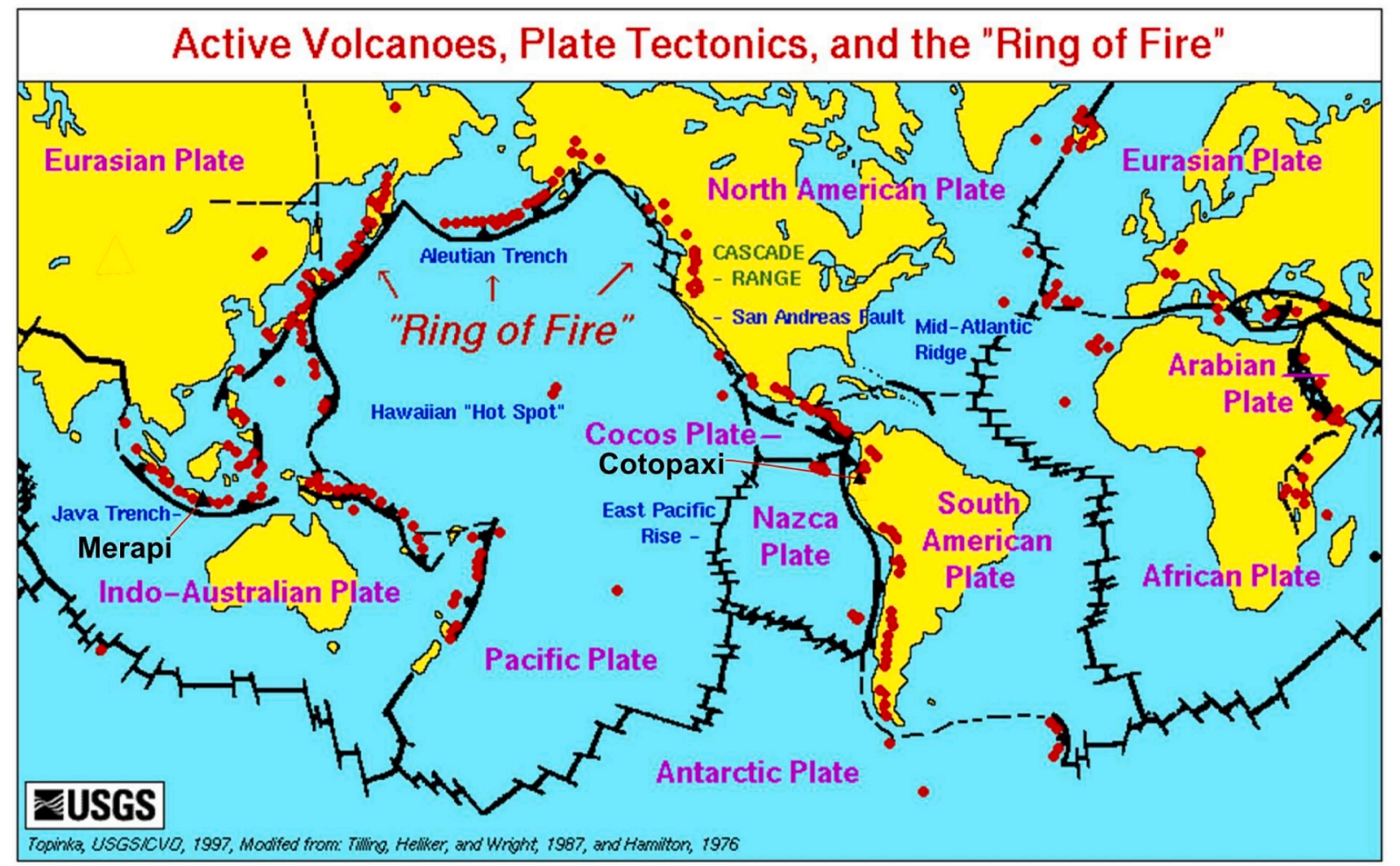

Fig. 1. World map on volcanoes and where the two cases are located, authors' adaptation (Wikipedia from USGS, 1997).

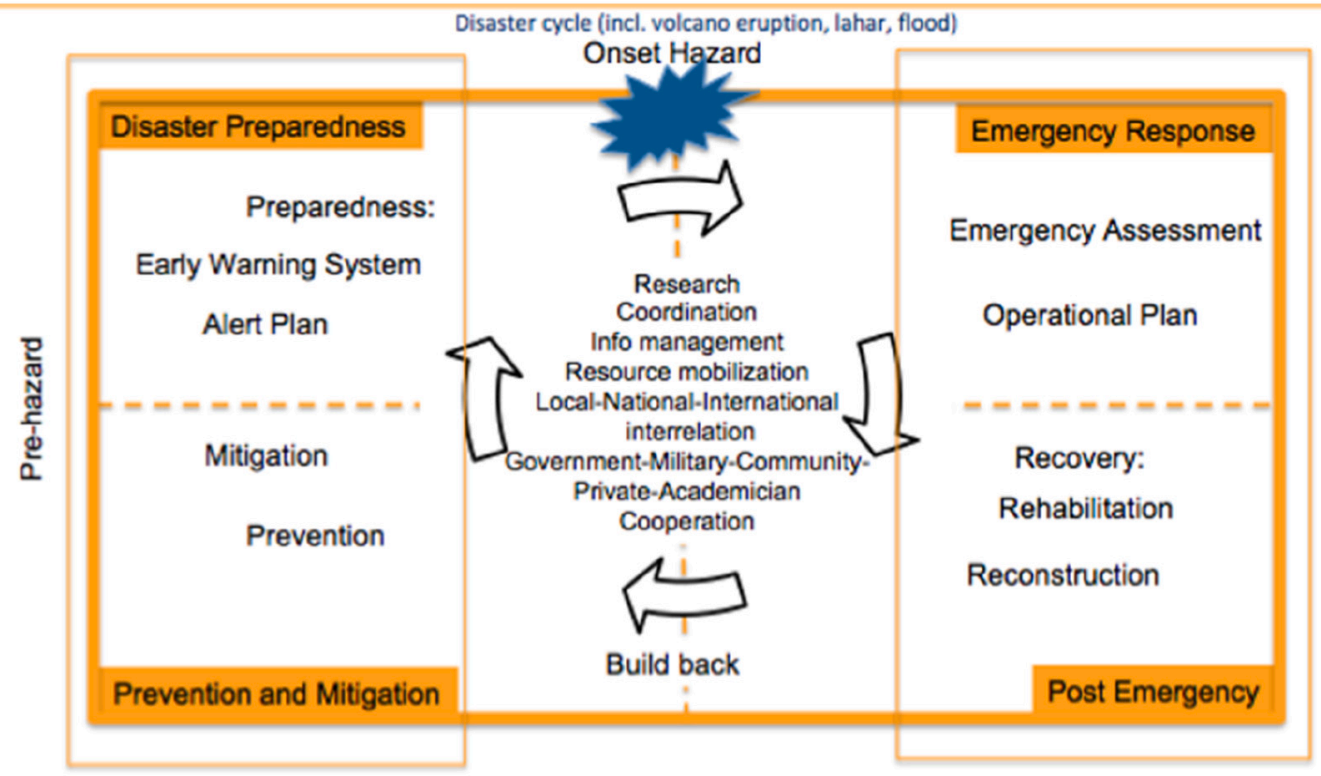

Fig. 2. Model of Indonesia's disaster management with the author's adaptation (BNPB, 2015).

Resources (KemenESDM) is the main actor in monitoring the volcano. This ministry is responsible for monitoring geological activity through an implementing body; the Geology Agency (Badan Geologi). ${ }^{1}$ It has

\footnotetext{
${ }^{1}$ The Agency performs the following functions: conducting research, investigation, and service in the fields of geological resources, volcanology, and mitigation of geological, groundwater, and environmental, geological disasters, as well as geological surveys. The Center for Volcanology and Geological Disaster Mitigation (PVMBG) performs the following functions, (1) prepare the formulation of technical policies for mitigation, (2) conduct research, (3) map hazard zones, (4) disaster risk analysis, (5) provides guidance of volcano
}

many branches in Indonesia, but lahar monitoring is put under the Center for Research and Development on Technology of Geology (BPPTKG) at the regional level (Ariyanti, 2019).

The key actor of lahar management at the national level is the Directorate General of Water Resources (DGWR), from the Ministry of Public Works and Housing, which has been supported by the JICA since 1976 for developing a disaster risk management plan for Mt. Merapi. Based on the volcano disaster mitigation plan, there are two types of

(footnote continued)

observers, (6) monitoring, evaluating and reporting on the implementation. 
hazards: volcanic eruption (direct impact) and rainfall (secondary impact) (JICA, 1976). Its guidelines for the management of direct impacts focus on non-structural measures (evacuation plan, land use plan, early warning system, and disaster response training). At the same time, the secondary hazards required structural measures (lahar management infrastructures) and non-structural measures (evacuation, training, and sand mining management) (DGWR, Yachiyo Engineering Co. Ltd, 2001).

Aside from these activities, the National Development Agency (Bappenas) runs 'business as usual', activities such as budgeting for the disaster fund as a way to prepare for different disasters. The component of the disaster fund at the national level is used to support the lower government levels. In this sense, its role includes funding measures for all kinds of disaster, including for Lahar disaster:

"BNPB (national) has his own 'on-call' funds because it has funds at the time of the disaster, but the BPBD (regional and municipal) also has a budget. Every year, the DIPA budget at the national level has a reserve fund for disaster. So the reserve is transferred over to the next year." A respondent from the Development Acceleration Team of Yogyakarta-TP5 DIY (January 2018)

Before the 2010 eruption, a highly top-down approach was implemented, which required huge investments from the government which was granted as a loan from the JICA to build the Sabo Dams, started the 1970s (DGWR and Yachiyo Engineering Co. Ltd, 2001). The RBO successfully rebuilt these lahar infrastructures. It is important to highlight, though, that most dams serve multiple purposes: irrigation weir, drinking water intake, and temporary bridges, which were not to be used during the rainy season, as well as for lahar disaster reduction.

There are two types of Sabo dams implemented at Mt. Merapi: closed and open (see Fig. 3). The closed type is used to completely stop the lahar sediment flow, at which the dead storage condition can happen. Meanwhile, the open type has the conduit/slit pass, which still lets smaller rocks and sand up to $50 \%$ of the discharge.

According to respondents in all sub-cases, even the older generation had no previous encounter an eruption as big as that of 2010. The latest eruption took place in 2006 and did not include major lahars:

"I can say, even the elders agreed, that we only knew (the eruption) last happened (in 2006). Even then, it only created a beautiful spectacle of lava flow from the summit. That was it, nothing more. The embankment flooded last in 1983. After that, we never had any flood in Opak." Respondent in Argomulyo

(July 2016)

The last lahars recalled were in 1983 . This history shows that the lahar floods do not occur with each eruption, but during one that is big enough and combined with the rainy season. The pre-eruption phase preparation training deals with readiness training of the $\mathrm{CBO}$ with the local BPBD. It took place more often in upper stream areas than the midstream and downstream. This condition is due to the impact of the hazards being greater upstream if compared to other locations. The $\mathrm{CBO}$ in the upstream area focuses their awareness on safety during hazards, where the disaster management agency also prepares additional training, evacuation routes, and meeting points.

The lahar hazard zone is mapped based on a historical review of earlier lahars. However, even if the safe lahar zones were not fully implemented, the 'sister village' program is established between the upstream and midstream sub-districts or villages to receive displaced residents. This sister program implied that whenever an eruption happened and had an impact to a certain radius, the upstream residents were to evacuate to the designated sister location. This program is supported by the municipal and regional disaster management agencies using the disaster fund. The fund is used in establishing evacuation tents, providing food, emergency supplies, and other helpful tools for individuals in the disaster region. Therefore, this support from the BPBDs.

As posed by a respondent:

"A sister village program exists between sub-districts. Like here, in Argomulyo, our (upstream) sister is Glagaharjo ( $4 \mathrm{~km}$ from the summit). But, our sister downstream is Kalasan (25km from the summit)." Respondent in Argomulyo (August 2016).

This phase highlights the pre-existing top-down approach to mitigate lahar risks in close-collaboration with the RBO constructing the Sabo Dams and providing the evacuation training, while the disaster management agencies prepared on-call funds, evacuation routes, meeting points, and the 'Sister Villages Program'.

\subsubsection{Eruption onset of Mt. Merapi}

The onset phase of the 2010 eruption began when lahars occurred after a rainfall of $200 \mathrm{l} / \mathrm{s}$ intensity on the flank of the volcano right after the eruption. The lahars flowed to the urbanized areas of Yogyakarta and significantly ruined everything on their path. The map in Fig. 4 shows the Mt. Merapi hazard zones within a radius of $30 \mathrm{~km}$. The distance from the summit to the beach is about $50 \mathrm{~km}$. It superimposed with an approximation of the Kartamantul (Yogyakarta-Sleman-Bantul) Agglomeration (on beige on the map). The red area delineates KRB 3 (most dangerous within $4 \mathrm{~km}$ radius) directly impacted with a pyroclastic flow. The pink area or KRB 2 (dangerous within $16 \mathrm{~km}$ radius)

\section{Open-type Dam}

\section{Closed-type Dam}

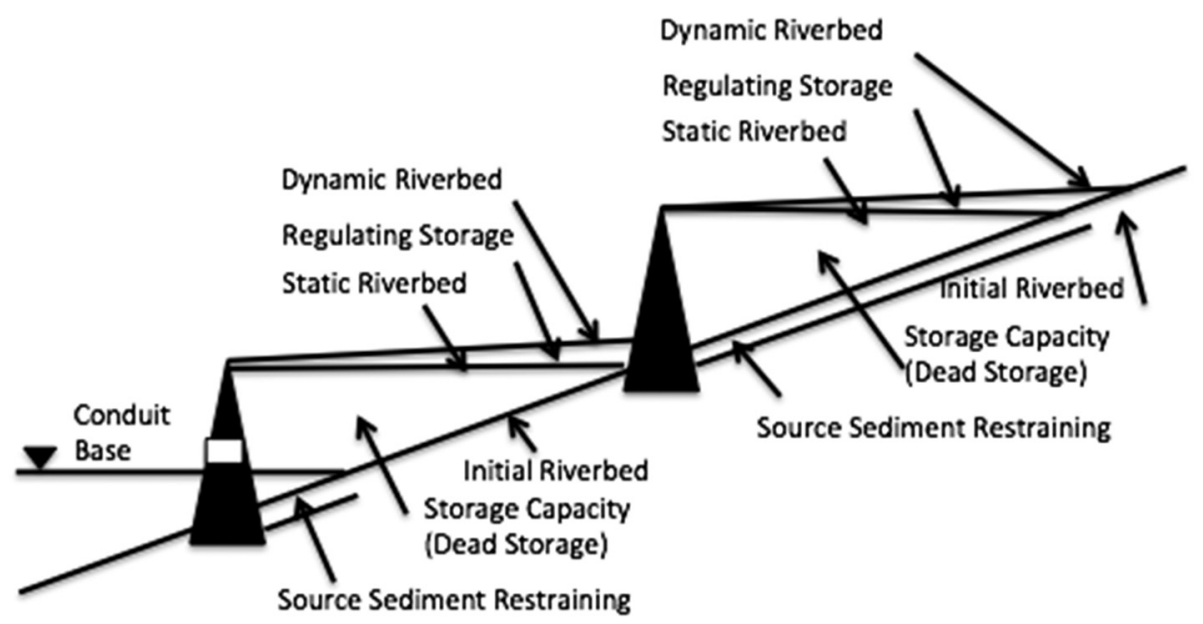

Fig. 3. Sediment Control by Sabo Dam (DGWR and Yachiyo Engineering Co. Ltd, 2001). 


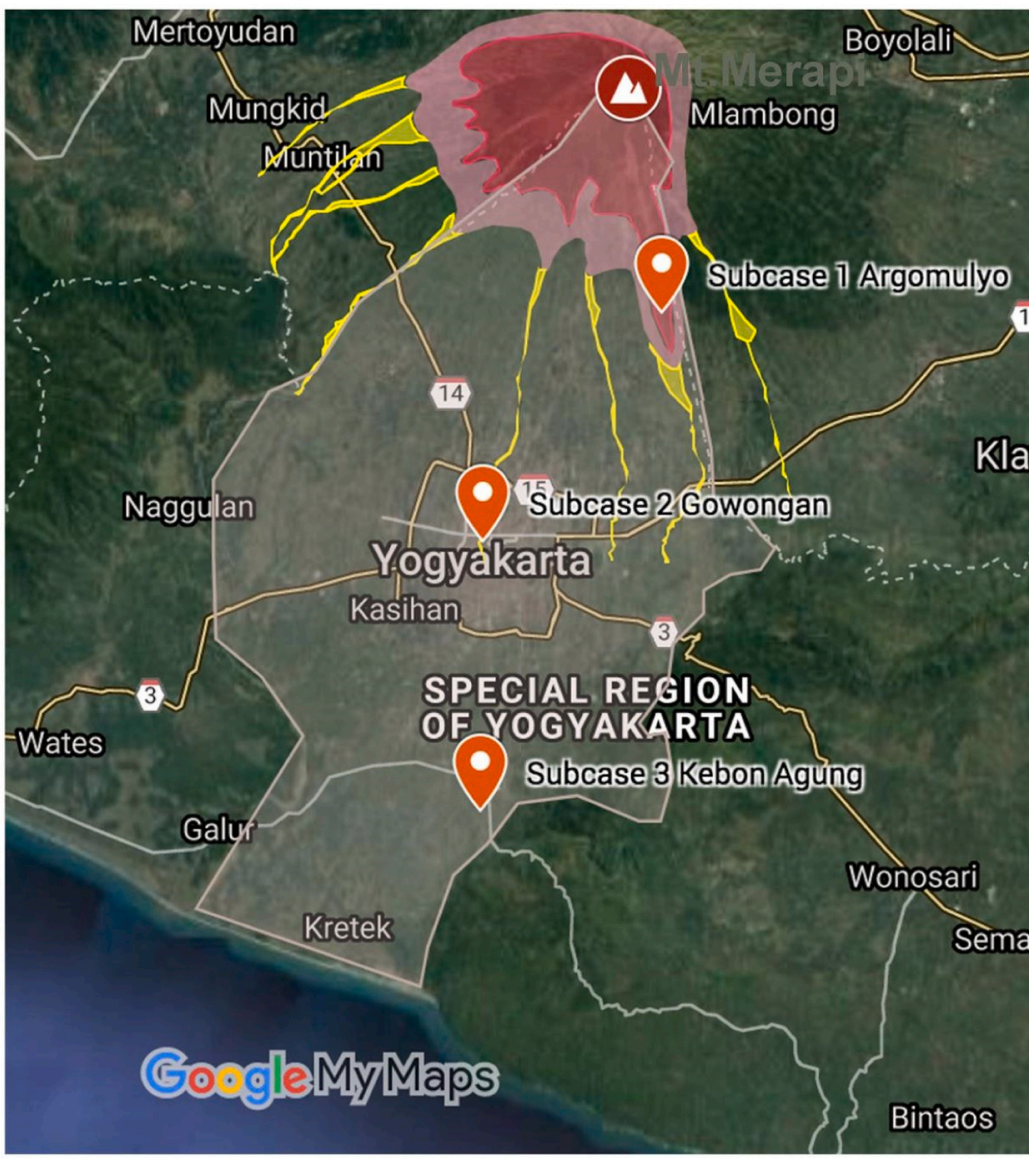

Mt. Merapi

Subcases

\section{Hazard zone 3}

Hazard zone 2

Hazard zone 1

Kartamantul

Agglomeration

Fig. 4. Hazard zones of Mt. Merapi in the Kartamantul Agglomeration and subcases location, authors' adaption from https://siaga.bnpb.go.id/CekPosisiMerapi

impacted both direct (pyroclastic flow) and indirect (lahar). Meanwhile, the yellow area or KRB 1 (less dangerous up to $30 \mathrm{~km}$ from the summit) is impacted with lahar flows.

In this phase, the main stakeholder was the Disaster Management Agency that took coordinating and commanding roles, a top-down approach. The National Level Disaster Agency (BNPB) was included as the onset of eruption and lahar affected two provinces, the Central Java Province and the Yogyakarta Special Region. Other stakeholders were involved with supporting roles: helping with evacuation, providing shelter, clean water, medicine, and food, also the mobilization of heavy equipment. This overarching framework is used by the BNPB operations, which were limitless as long as the main idea was to maintain safety and order during disaster events. ${ }^{2}$

The first subcase is the city of Argomulyo located in the KRB3 zone, $15 \mathrm{~km}$ from the summit, in the Sleman Regency region and was submerged by the lahars as seen on Fig. 5 below (Camus et al., 2000; De Bélizal et al., 2013; Donovan, 2010; Dove, 2008). This location is also home to numerous Sabo Dams (lahar infrastructures), which were not built to sustain the pyroclastic flow. These dams became barriers and were also the reason why the pyroclastic flow hit this area the hardest.

Despite the severe impacts, specific reports on the housing damage upstream have not been reported by international scholarship so far.

\footnotetext{
${ }^{2}$ The Indonesian policy on DRR encompasses all types of disasters in their Renas PB. Based on the disaster management law, there are channels for international aid to reach affected locations. The national government acknowledges this aid in the form of grants or loans. Another ministry, which relates to disaster management, is the KemenPUPR or the Ministry of Public Works and Housing. This situation has to do with their tasks in water hazards mitigation as one of the main pillars of the Indonesian IWRM (Asian Development Bank, 2016, UU No.7/2004, 2004).
}

Their houses were either burnt by the pyroclastic flows or buried under lahars. The condition is seen in Fig. 5 resulting in 300,000 residents evacuated from Sleman Regency to temporary shelters downstream, either in campsites, stadiums or at relatives' homes, for at least six months until the government sorted their relocation.

During this eruption phase, the municipal disaster management agencies (BPBD's) collaborated with a volunteer forum (FKSB), especially in evacuation activities, combining a top-down and bottom-up approach. Those joining the volunteer forum shared reliable information regarding the status of the volcano and the water and lahar levels in the rivers. They also communicated through radio (walkie-talkie), and collaborated with and evacuated to its 'sister' downstream.

The second subcase Gowongan is located in the city center of Yogyakarta (located in KRB 1), where around 500,000 residents were impacted by the lahar, particularly the housing located by the riverbeds, which were submerged. The condition of the river is described as follows:

"During (the 2010) eruption, when I went to the river, it was only like this (stepping). The sand deposition is about 2 meters deep." Respondent in Gowongan

(July 2016)

This location had a more active role from the community through the collaboration of the regional and municipal disaster management agencies. The community forums called the Paguyuban RW helped not just evacuation from the riverside but were also responsible for the survival kit throughout the two months of lahar flood from December 2010 to February 2011.

The Paguyuban had a significant role as intermediaries and facilitators in holding the community together and collaborating with the disaster management agencies and the municipal government. The 


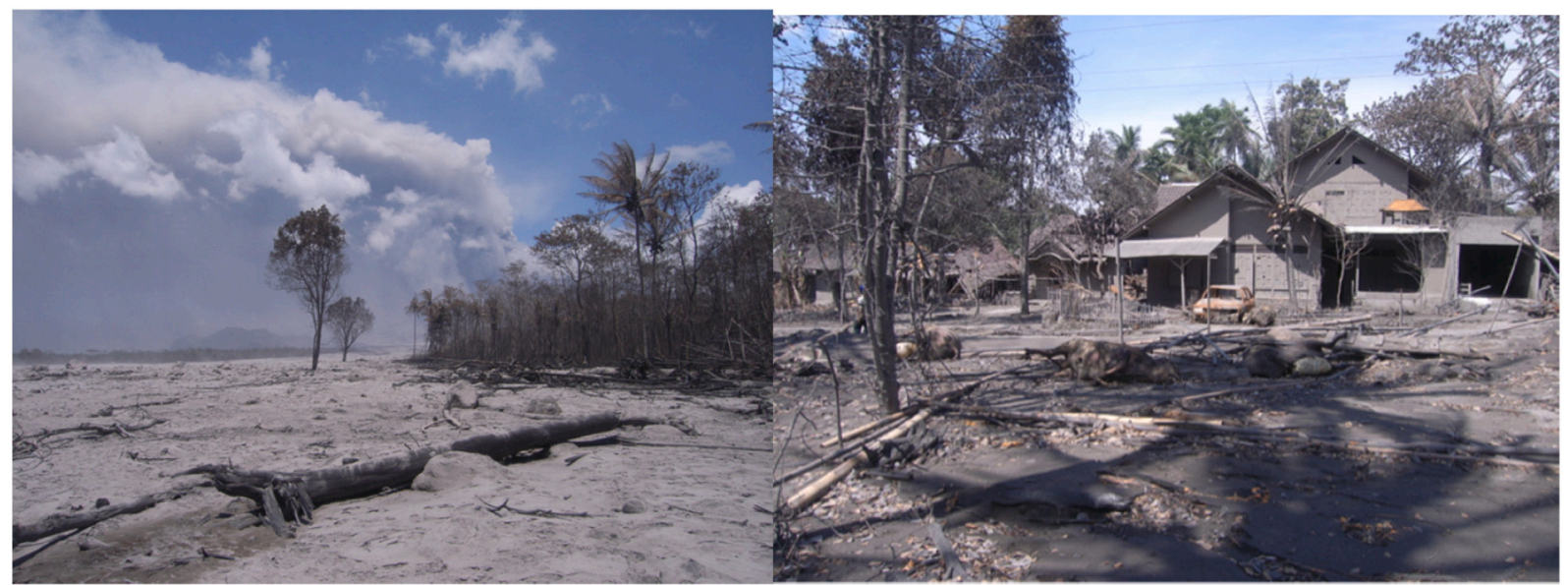

Fig. 5. (Left) Condition Gendol Tributary during 2010 eruption and (Right) condition at subcase 1 urbanized area (BBWS SO Documentation, 2010).

inhabitants stayed on higher grounds as long as needed, by occupying their neighbors' homes. Their survival was also based on the river community watch from upstream to downstream, as referred to in subcase 1 . The city-level disaster management agency helped in the evacuation, but the local community did most works. This fact supports similar research on community resiliency in the face of a disaster (Mardiasmo \& Barnes, 2010; Norris et al., 2008; Stone et al., 2014).

Subcase 3, Kebonagung is located almost $50 \mathrm{~km}$ away from the summit of Mt. Merapi, in the urbanized agglomeration of Bantul Regency. Despite the distance, during the lahar flood, they also suffered from the rapid sedimentation of the rivers. Lahar made the riverbed silted and soon enough the riverside transformed into plots of land. The inhabitants were not ready then, because they never experienced anything like this. The river was completed with an irrigation weir that was suddenly silted so badly, water overflowed to nearby houses by the river and submerged much of the irrigated farmlands. The regency-level disaster management agency did nothing, as the lahar flow was almost as fluid as usual water flood and only flooded non-residential areas. However, the sub-district government helped in establishing the disaster response team, which began to take heed of the water level and take turns reporting to other inhabitants when floods were coming.

\subsubsection{Post-eruption}

In this phase, which was six months after the eruption until the next four years-cycle eruptions, the main stakeholder of the volcanic river basin was the river basin organization. The disaster management agencies (BPBD and BNPB) were no longer in command. The river basin organization (RBO) retook charge in implementing Indonesia's IWRM approach in river basin planning (Asian Development Bank, 2016, UU No.7/2004, 2004) by providing safe access to water (utilization pillar), conserving water sources (conservation pillar), and reconstructing the Sabo Dams (hazard control pillar) (BBWS SO, 2016). The Sabo dams, irrigation channels, roads, houses, bridges, which were submerged were excavated and dredged from lahar materials. The inventory of collapsed and destroyed infrastructures was done, prioritization lists were made, and later, the river basin was filled with infrastructures' rehabilitation and reconstruction activities.

As the old cycle of Mt. Merapi eruption was four years, based on 10,000 years of its eruption (Newhall et al., 2000), the pre-eruption phase was decided after the 4th year had passed. With the volcano being less active and the preparation for the next eruption was ongoing, most of the Sabo Dams were completely restored, and even a new series of dams were constructed within five years after the 2010 eruption.

Based on the lahar management concept using the Sabo Dams system, the current implementation is the combination of the open and closed type dams (seen in Fig. 6). This combination is performed to filter the size of the volcanic materials flowing in the river. The Sabo dam system in Mt. Merapi works in managing lahar using the filtering strategy.

Bigger boulders use open type and sand pockets for upstream Sabo; closed type with holes between up to midstream with the help of diversion channel; embankments for midstream, throughout downstream areas where needed. Out of the 102 Sabo dams, 58 have other functions, either as intake or Oprit (bridge) or both.

While the whole volcanic river basin is filled with a series of lahar infrastructures, which include Sabo dams, dikes, and channels, the management of this VRB is dissected between stakeholders and their overlapping jurisdiction. The following Fig. 7 illustrates the condition. The stakeholders are presented in the diagram and arranged as follows:

(1) Regional Development Agency or Bappeda DIY: all space in regional administrative during pre and post-disaster.

(2) Regional Disaster Management Agency or BPBD DIY: all space in regional administrative during onset disaster.

(3) Regional Public Work Agency or PU-P ESDM: all infrastructures belonging to the provincial government and management.

(4) Serayu Opak River Basin Organization or BBWS SO: under the KemenPUPR for all the rivers, lahar and flood, including floodplains and the Sabo Dam infrastructures.

(5) Volcano National Parks or BNTGM: under the KemenLHK, the national park of Mt. Merapi- scales of management: $4 \mathrm{~km}$ radius from the summit.

(6) Volcano Center or BPPTKG: under KemenESDM on the Mt. Merapi's volcanic activities are monitoring - scales of management: the whole Mt.ain up to its flank and the rivers where the volcano channels its debris flow.

(7) Catchment Management Authority of Serayu Opak Progo or BPDAS SOP: under the KemenLHK, for all catchment management especially for water retention inland.

Conditions in the subcases varied based on location and activities. In subcase 1, the upstream urbanized area of Argomulyo and home to the Sabo Dams, normal life activities resolved with inhabitants resettling into new homes about $2 \mathrm{~km}$ away downstream. The location they left behind was an eerie 'ghost town' with houses half-buried, roofs burned, and houses smashed by boulders the size of full-grown elephants. The volunteer forum members went back to their farming and other activities. The inhabitants learned new facts that sand from the volcano is economically valuable; it is like 'black gold' since the sand was categorized as the first quality for building materials (Ariyanti, 2019).

Between 2011 and 2015, additional sabo dams were built to increase lahar control. The riversides were barren of inhabitants, as they 


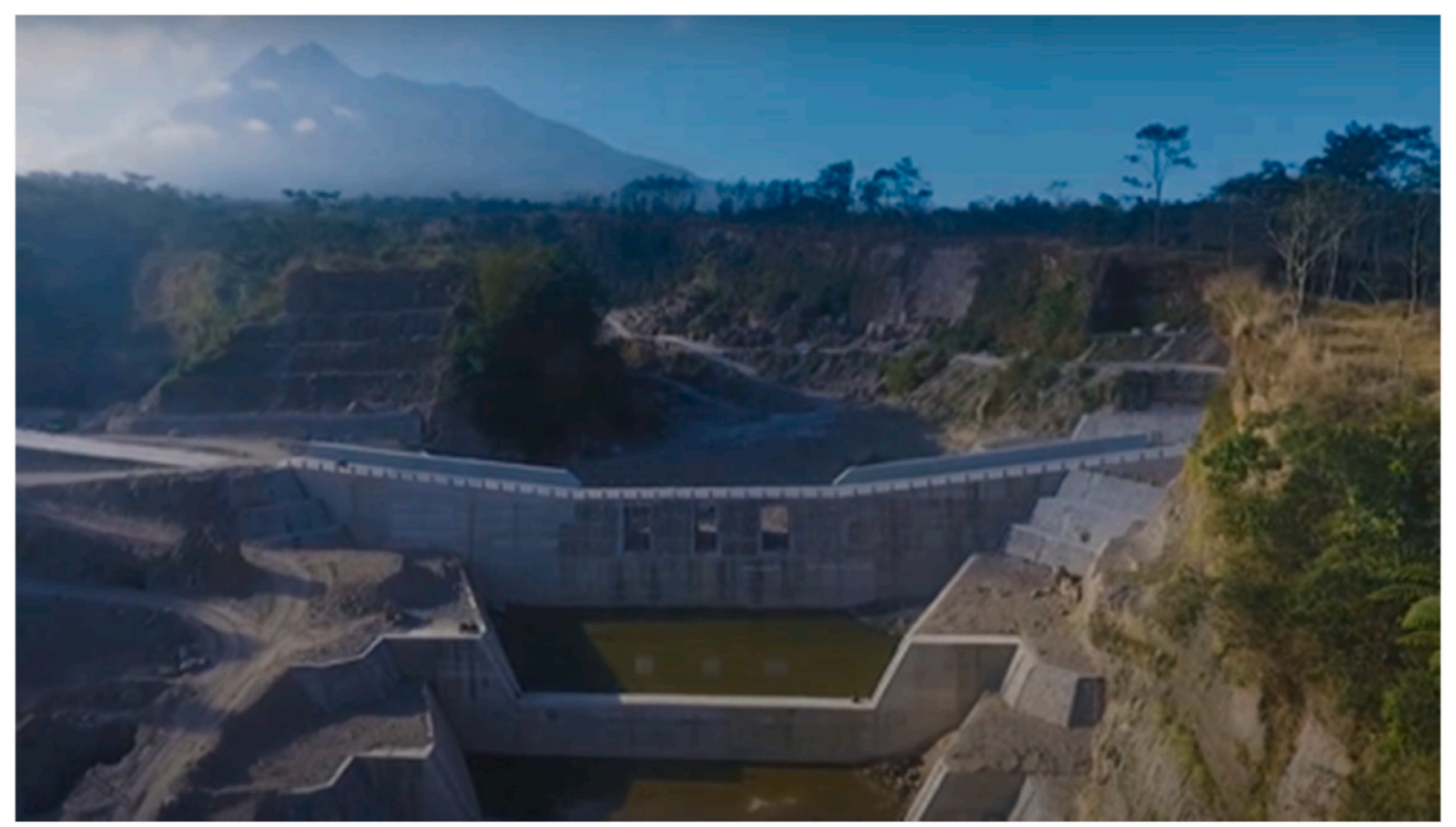

Fig. 6. Multi-function open-type Sabo Dam (irrigation weir and bridge) in Subcase 1 after rehabilitation (Documentation BBWS SO, 2018).

had come to understand the risks living too close to the Sabo Dams can have on their life. The RBO helped with risks and evacuation training for the volunteer forum members, as part of a participatory strategy where top-down and bottom-up approaches collaborated. The RBO has completed most of the Sabo dam reconstructions, of which more than half have multiple functions such as temporary bridges, irrigation weir, or drinking water supply intakes. These other functions are included, as resistance to having a Sabo dam was rising. All activities on water resources management went back to normal. However, at the same time, sand mining also affected the groundwater by the riverside, as the mining cut the water flow in many riverside locations. In river areas, the lahar sedimentation is used as paddy fields.

Many inhabitants were lured from farming to sand mining activities (based on 2016 and 2018 observations). The lahar and stones deposits from the eruption were about $5 \mathrm{~m}$ deep from the original elevation. This attracted sand miners from far-reached locations and hundreds of

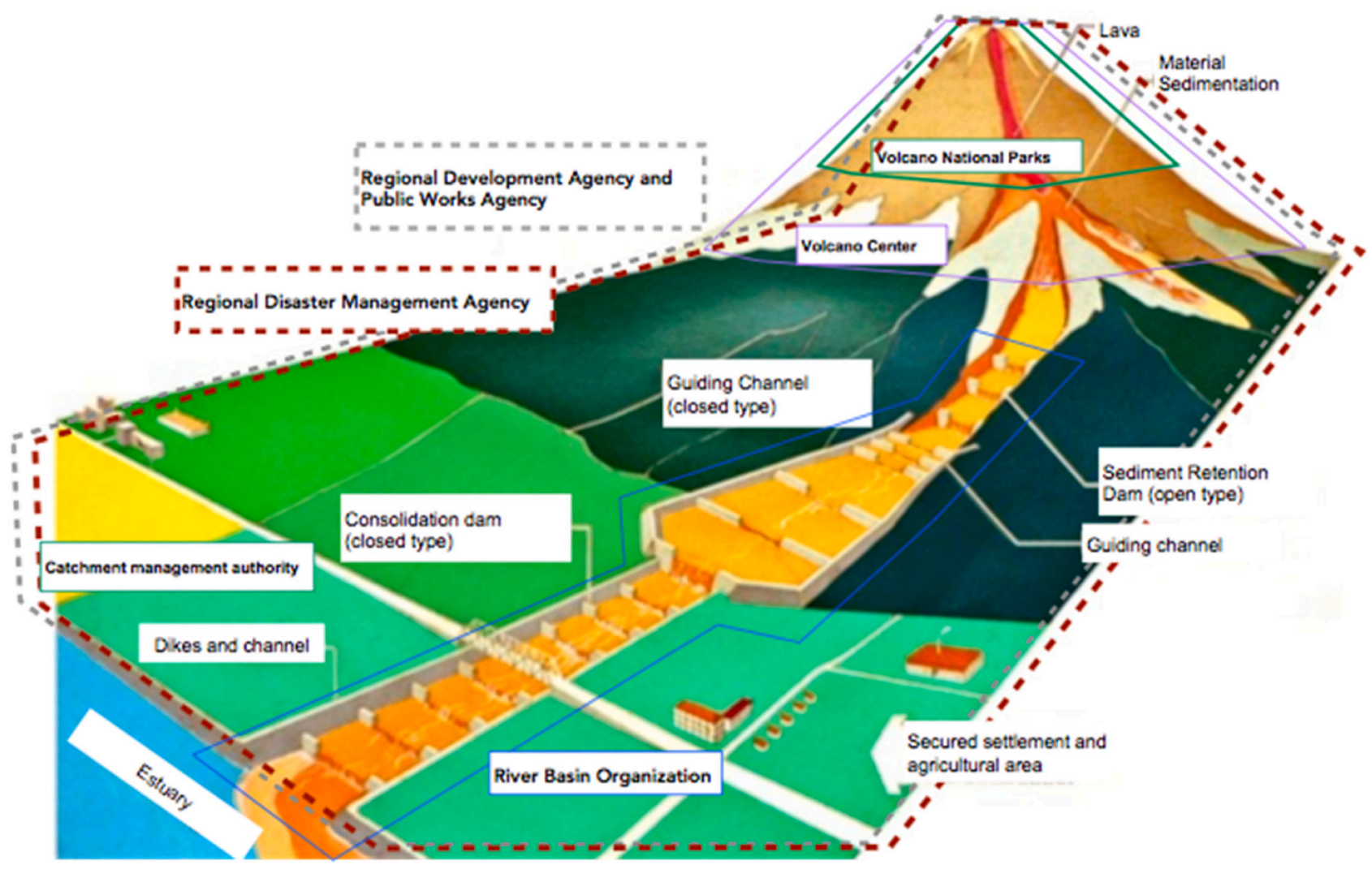

Fig. 7. Sabo Dams system and stakeholders' jurisdiction volcanic river basins of Mt. Merapi elaborated from (BBWS SO, 2011). 
trucks loaded volcanic material from the area. The increased activity, however, was out of the sub-district government control, as the mining permit was through the regional government. The RBO collaborating with JICA through consulting services (DGWR and Yachiyo Engineering Co. Ltd, 2001) produced a guidebook for community participation in controlling the mining activities, which include calculating the truckloads by metering them by the checkpoints. This way is a top-down approach trying to reach out to the bottom-up approach, through community participation, which was not yet effective, as the community did not feel involved enough to report to the RBO. If there were any reports, they were not enforced by law, as over-mining was not considered as illegal, but only against the mining permit.

After 2015, the regional government had more control through a mandate to issue mining permits. Yet, small scale sand mining activities still occurred with almost no control from the regional government, as they mined on their plot of land by the river and were not easily detected. The danger of over-mining for upstream areas is imminent; the RBO's role in stopping this is limited to stopping the release of new technical recommendations for sand mining activities in the rivers. The over-mining of riverbeds and riversides in Sabo Dam locations were becoming more concerning and dangerous, as no apparent massive lahar flows can refill the rivers' body and the Sabo Dams areas.

Subcase 2, Gowongan is located near the Tugu (a landmark of Yogyakarta City), which includes the Kampung Jogoyudan; a riverside location of informal housing. The area was submerged in up to $1 \mathrm{~m}$ of lahars, and inhabitants decided to keep the new ground elevation and use the extra sand to build second floors to their houses. The Paguyuban RW had a leadership role for direct aid from international agencies. Inhabitants were accepting aid to reconstruct their houses, which can still be seen from the type of roofing material used (asbestos), as opposed to the traditional red clay tiles. The RBO helped in excavating the lahar materials from the river channel and gave the materials to the inhabitants to use. The wells by the riverside were contaminated with sulfur, but after a good dredge, the water could be used.

After 2015, no further problems occurred in the city center of Gowongan. However, the riverside houses at Kampung Jogoyudan had an unusual appearance as they were surrounded by an elevation higher than their front door. Paguyuban RW continued to actively monitor water levels during the rainy season, but no real flood potential occurred. The RBO also helped in reconstructing damaged levees. However, the original levees were built by the city's public works agency, and there were asset management problems, which was solved with the letters of inadequate budgeting from the city level.

This subcase displays an example of effective governance by combining a top-down and bottom-up approach. The lahar sedimentation in the river body is used as urban farmlands, where cassava, vegetables, and bananas were grown. Water problems resulting from the lahar sedimentation were completely taken care of after good dredging of riverside wells were done. No signs of sand mining problems occurred, as not much sedimentation took place in this location.

A top-down approach met the collaboration of the bottom-up approach. Both approaches are working together in minimizing the impact of lahar. The location and timing also help, since it is in midstream, after the 2011 lahar excavation, no lahar sediment was deposited too long here.

Subcase 3, Kebonagung is located in the boundary of the Bantul urban area. It had help from the RBO in dredging their river and weir areas. The river was still silted as new lahars formed every time heavy rain fell. Before the 2010 eruption, the sub-district had organized a tourism secretariat, as the location used agricultural tourism as their tagline. The tourism activities included Dragon Boat festivals during the Chinese New Year celebration, but due to siltation, these activities could no longer be held. Apart from that, the sub-district now became aware of flood potential during the rainy season. Additionally, now the inhabitants own a full-fledged disaster response team.

However, the disaster response status only lasted one year after the eruption, so the RBO can no longer help the dredging efforts, as the weir is under the provincial jurisdiction. Also, since the lahar sedimentation got harder, it formed the riverside areas with tall grass. This alluvial sedimentation is fertile since it has volcanic materials in it. Inhabitants used the riverside sedimentation as non-irrigated farmlands. Continuous farming activities were found on lahar sedimentation areas, with grass for cattle being the favorite, aside from corn, cassava, and bananas. Sand mining activities were observed in weir locations (2016 and 2018 fieldworks), where sedimentation was forming. The mining was considered illegal, but not on a big scale. Miners used manual methods by diving into the river and extracting the sand and aggregates using woven bamboo containers, which also function as a sand filter from the river's water. The activities were found as unsettling for the weir operators and communities, as the miners are not locals, and it is not their duty to call-off the miners, as none of them has the authority. Both the weir operator and communities hoped the RBO could do something about it, yet, there has been no action done, up to 2018.

The top-down approach, in this case, included only minimum effort, while bottom-up strategies seemed less concerned about the lahar impacts. The community continued to uphold tourism and farming activities, nonetheless. The bottom-up approach does more activities in this subcase, but not met with a supportive top-down approach, and proves to be less effective.

\subsection{Case-study 2: Latacunga, Ecuador and Mt. Cotopaxi}

The second case study, located in Ecuador (South America), looks at risk management from the perspective of households after a volcanic eruption in 2015 triggered various policy and planning changes. The case looks at how bottom-up risk management strategies interact with top-down governance policies to manage risk within the risk governance structure.

Ecuador is a country on the east coast of the Pacific Ocean that is home to over 80 volcanoes, of which 27 are potentially active (La Hora, 2016, IG EPN). The type and intensity of volcanic activity differ significantly between them. However, the highest and most dangerous is Mt. Cotopaxi. The stratovolcano located in the northern Andes volcanic zone is $88 \mathrm{~km}$ from Quito the capital and threatens the lives of over 32,000 people due to its ability to produce deadly lahars (Mothes et al., 2017). The cement-like flows can potentially be generated by vast amounts of snow melting from the volcano's summit during long periods of activity.

Cotopaxi threatens several cities including Quito, and the agglomeration of Latacunga to the south, downstream from it. Latacunga canton is the main city within Cotopaxi province, throughout its history, it has been devastated by volcanic lahars which severely impacted its population, economy, and development (Bromley, 1979). However, while the risk is known, people returned to Latacunga and continue to reside in areas previously impacted by lahars.

Within the last 500 years, Cotopaxi has had five main eruptive events in 1532,1743, 1744,1768, and 1877 (Fig. 8). The latest and most well documented was the 1877 eruption which was a VEI 4 (Mothes et al., 2017) where lahars lead to devastation similar to that of Armero in the 1985 lahar disaster (Mothes \& Vallance, 2015). Since then, Cotopaxi remained silent with minor activity under the surface until in 2015 an increase in the volcano's activity was observed by geoscientists (Crafford \& Venzke, 2016). Although ash and gas were dispersed, it was considered a minor eruption as no magma or lahars were produced (Mothes et al., 2017).

In 2008 a new constitution was established in Ecuador that adopted a decentralized system for the first time and assigned the responsibility of disaster risk management to local governments. The Secretary of risk management was formed as the national entity responsible for managing risk and currently has departments in all other ministries. These ultimately support local governments in the planning and management 


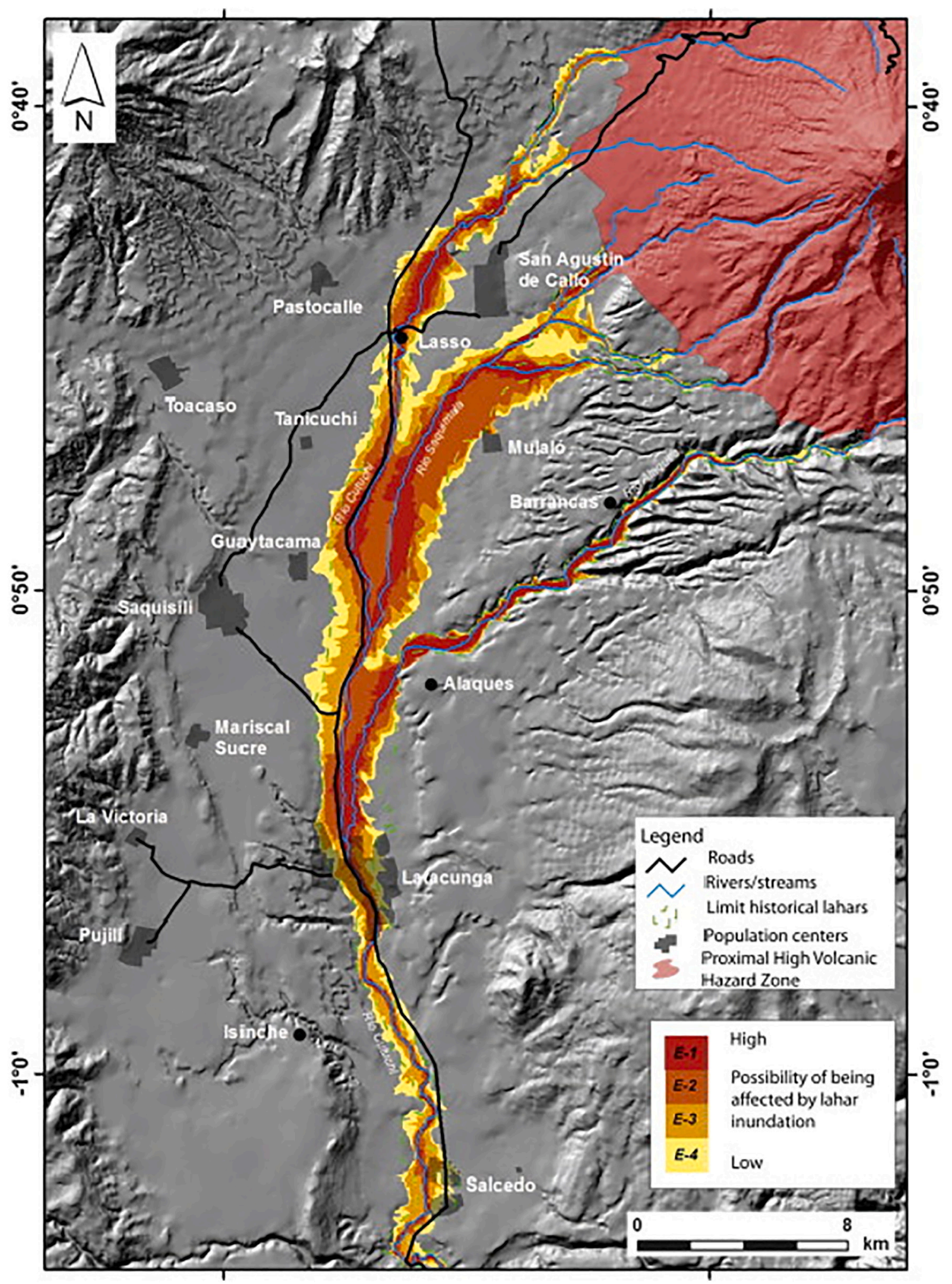

Fig. 8. Cotopaxi and its surrounding urban areas (Mothes et al., 2017).

of risk but do not undermine their autonomy (Stone et al., 2014).

\subsubsection{Pre-eruption}

The secretary of risk management is responsible for the preparation of DRM strategies that are integrated from national to parish levels of government to prevent, respond to, and build post-disaster (Secretaría de Gestión de Riesgos, 2017). These include managing various types of risks, such as earthquakes and landslides and are not limited to volcanoes. An interview with the representative from the national service for the management of risk and emergencies (NSREM) highlighted that risks are prioritized according to urgency, as the country is prone to various natural hazards. Consequently, as Cotopaxi had not shown visible activity for an extended period (Mothes et al., 2017), less attention was given to the volcano and the general belief amongst citizens 


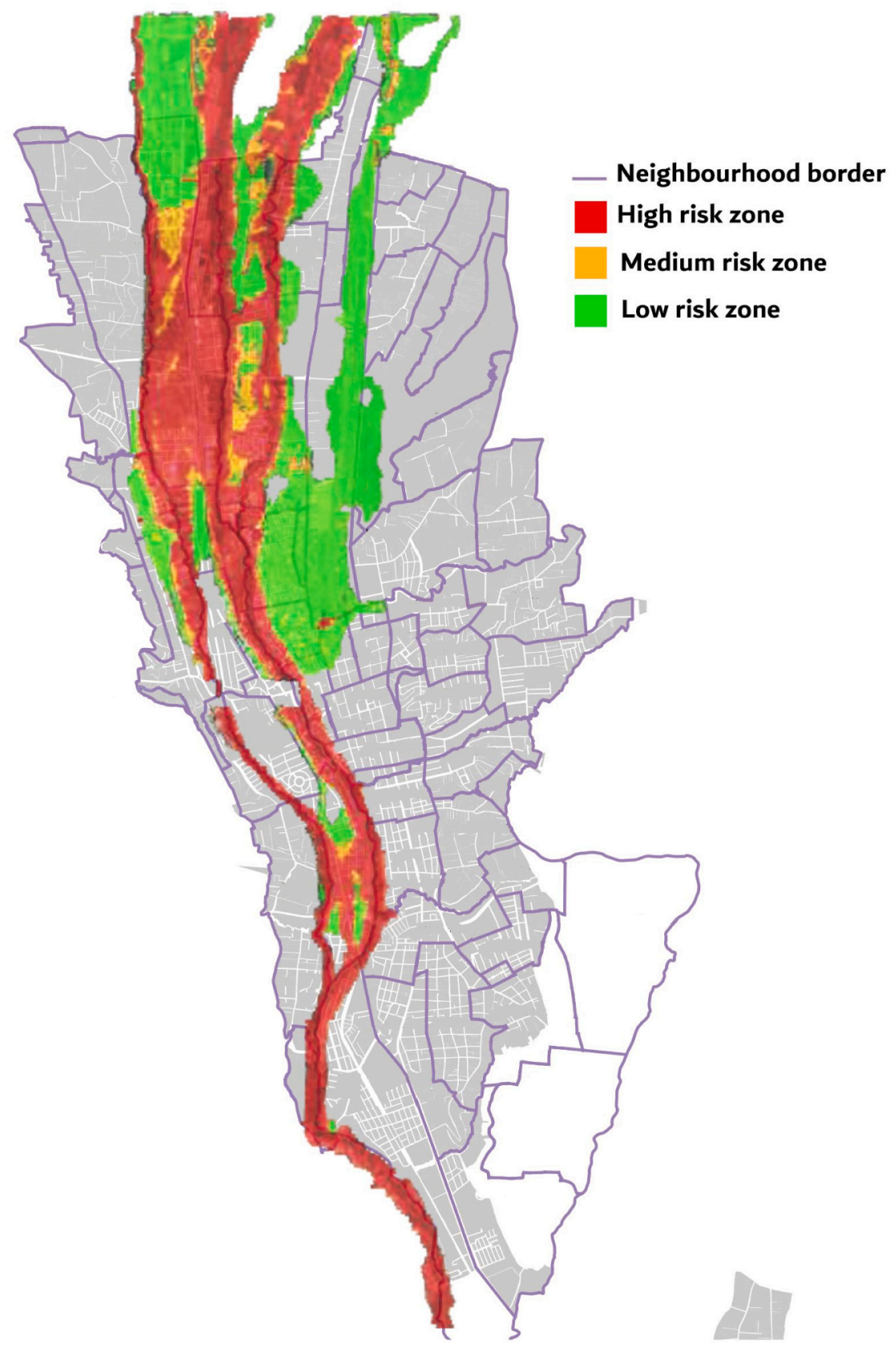

Fig. 9. Latacunga risk zones. (Adapted by author from Latacunga LUMP).

was that it would not wake again (Gaafar, 2019). This condition was despite stories of the previous eruption being part of the city's history and the celebration of the yearly "La Mama Negra" festival in memory of the last eruption.

The entity directly responsible for managing risk at the local level during this phase was the local government. Today, evacuation signs are visible around the city and evacuation centers known to citizens. However, before the 2015eruption land management policies prepared by the local government did not demarcate areas previously flooded by lahars. No building regulations specific for risk areas were enforced, and the two main hospitals in the city were constructed near the river in the highest risk zones. Moreover, while a monitoring station had been present at the volcano since 1976, direct communication channels similar to those established at Tungurahua volcano for example, between scientists and the citizens of Latacunga were scarce (Mothes et al., 2017). Such channels were essential to building trust between scientists and citizens, and in the dissemination of scientific information and the resulting actions in case of an eruption (Stone et al., 2014).

\subsubsection{Eruption onset of Mt. Cotopaxi}

In April 2015 - after relatively no activity for over seventy years -, a restlessness in Cotopaxi volcano occurred as deformation, ash plumes and ashfall, SO2 emissions and fumarolic activity were all observed by IG EPN the entity responsible for monitoring seismic activity in Ecuador (Crafford \& Venzke, 2016). The volcano released ash and gas columns reaching nine kilometres over the crater, reviving the risk of volcanic lahars that had previously devastated the city of Latacunga (Gaafar, 2019). Volcanic activity continued for five months, during which the president declared a state of emergency and hundreds of people were evacuated from the city (La Hora, 2016).

Although ash and gas were dispersed, the eruption never surpassed a VEI of 2 as no magma or lahars were produced (Mothes et al., 2017). Nevertheless, at six in the morning of the 15th of August 2015, a local radio station in Latacunga announced that the alert level for the 
volcano was raised to red (the highest danger level) and urged people to evacuate:

"They said we are talking right now with a volcanologist and we want to alert you that at this moment there was a huge explosion, we can see lahars coming down! So please everyone evacuate because something terrible is going to happen so, please leave!"

El Rosario Respondent describing his experience with the 2015 event (July 2019)

The city's mayor made the announcement, and while a protocol exists at the regional level to handle such situations, it was not activated as IG EPN did not increase the danger level. As the integrated central security system declared:

"We were watching the screens, and suddenly people began to run and panic, we did not understand what was happening." The respondent from the national CCTV

(July 2019)

The event caused major havoc, fear, and confusion throughout the city (Toulkeridis et al., 2018). Interviews and news articles indicated that some residents abandoned Latacunga permanently (El Comercio, 2015), and while interviews showed some residents returned to the city no official data was found to illustrate how many actually left or came back. Although the volcano did not produce lahars, the event was a milestone for Latacunga as it reawakened the fact that Cotopaxi is still an active threat.

Risk management strategies applied by both citizens and the government during this phase included avoidance of the risk through evacuation and permanent resettlement. The main stakeholder changed as an Emergency Operations Committee (COE) was established at the regional and national levels to coordinate between different stakeholders and manage the disaster risk (Mothes et al., 2017).

\subsubsection{Post-eruption}

After the 2015 eruption, several changes were made at the national and local levels, including the addition of new divisions for planning, monitoring, and supervising DRM. Interviews highlighted that while a high level of planning and supervision is done at the national and provincial levels, the municipality continues to be the main execution body and carries the responsibility of managing risk in its territory. Hence, after 2015 the local government undertook more stringent actions to protect vulnerable areas from lahar risk. The municipality's planning directorate integrated the newly produced risk maps from IG EPN into the new ordinance of the land use and management plan (LUMP). The LUMP ordinance is a policy document that regulates land use within the city and identifies high, medium, low, and none risk zones in Latacunga Canton (Fig. 9).

The LUMP outlined new building regulations and identified highrisk areas as non-building zones in addition to limiting building heights and uses in the risk zone. The land use and management plan were rereleased to the public in 2017 but met with demonstrations from those living in the high-risk zones. They formed a group under the name La Zona Muerta (The death zone). They managed after negotiations to modify the document adding clauses to secure their right to compensation and obligating the local government to prepare a vulnerability study and evacuation plans for the city.

The new local government recently appointed at the time of this research (July 2019) was planning to construct protective structures under the volcano. None have been built for Cotopaxi before however this view was shared and encouraged by citizens in the high-risk zones who saw that while evacuation is important, such measures could help reduce the risk.

Whereas the survey and interviews showed evacuation to be the main strategy relied on by the government and citizens in case of disaster, their perspectives vary. Evacuation plans made by respondents differ significantly from the official plans. Fig. 10 shows the evacuation plan described by an interviewee from the Nueva Vida neighborhood. He used the municipality evacuation plans as a reference to how he plans his evacuation from the city in case of a lahar descent from the volcano (Gaafar, 2019).

The research showed that households tended to rely less on strategies that were specifically dedicated to the risk such as technical modification to the building and the purchase of insurance. This can show little awareness about the importance and the existence of such options as most official programs focus more on evacuation and relocation but could also reflect a lower willingness to invest solely in protection from risk (Gaafar, 2019).

Although the volcano did not produce deadly lahars, the change in policy acted as a trigger for change and made the threat more real for citizens. Residents also gained knowledge about the lahar risk from secondary sources such as media, public events, and schools. These sources while secondary have proved to impact the actions people take to protect from lahar risk.

\section{Discussion}

In both cases, the governance structure and authority management brought several differences that influence both the perception of the volcanic eruption and lahar risk management. Therefore, in this discussion, we consider: the importance of the geographical background; the institutional framework and defragmentation in powers and authority during the different phases of an eruption; and what the onset phase implied to housing and urban planning. We conclude with a possible framework to coordinate IWRM and lahars mitigation.

\subsection{The geographical background that changes everything}

In Java, Mount Merapi is an active volcano, which prior to the 2010 eruption, erupted every four years, although not all were considered major ones. Unlike the lahars of Merapi, which is active on a much shorter time cycle and triggered by rain, Cotopaxi operates in a 100year cycle, and the lahars are triggered by snow melting from its summit (Mothes et al., 2017).

\subsection{Institutional framework and defragmentation in powers}

The governance and stakeholder functions in both cases permeate a set of regulations. These regulations unveil actions and blockages of governance. In Indonesia, the institutional frameworks are there for each of the aspects of volcanic river basin: water management (RBO), spatial planning (development agency), and disaster management (agency). There, more involvement from the central government during the different stages of the eruption, while in the Ecuadorian case, this occurs mainly during the onset phase. Nevertheless, there are jurisdiction boundaries for each institution that create limits for effective integrated management of resources.

In the case of Mt. Merapi, the fragmentation is further convoluted with the shifting of roles during pre, onset, and post-disaster. However, it is also a necessary move to comply with regulatory and policy enforcement. The Indonesian case study presents the flexibility of changing roles between stakeholders and proves that the onset disaster phase is where integration is achieved. Lahar risks management uses a more top-down approach, where the government and donor's investment were to build the Sabo dam systems as lahar infrastructures.

On the other hand, in Ecuador, the legal framework's concurring authorities reflect on unclear divisions and attributions. Local governments manage risk and spatial planning with supervision from national institutions. Water, however, is managed through a different structure that is headed by indigenous leaders. This condition highlights the defragmentation in powers and further challenges environmental management to take a holistic approach. 


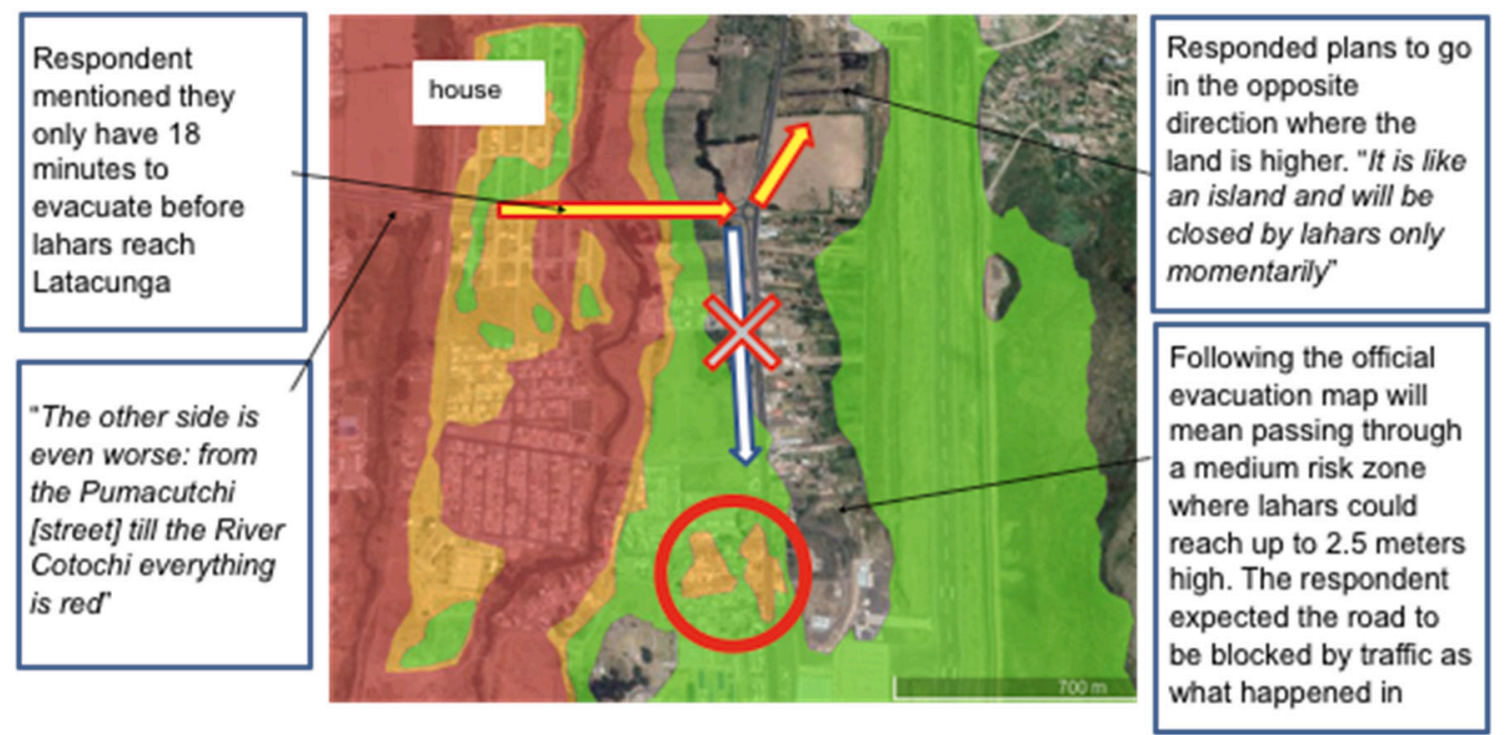

Fig. 10. Evacuation plan (based on interviews).

\subsection{Planning and housing during the onset phases}

During the onset phases - the eruptions - is when urban planning and management, as well as the impact on housing, become more relevant in both cases.

In Indonesia, communities played more active roles in the emergency response, as the disaster management agencies could not help everyone during the eruption. This redistribution of powers suggests that local communities have an essential role to play and shall be listened to inform better risk planning. However, this citizen participation at the significant processes that constitute risk management is not an easy task, as it requires regional attempts and actors to manage the whole river basin.

On the other hand, the Ecuadorian case study found that social networks and proximity (zoning policy) play an important role in where and when communities decide to evacuate. Bottom-up and top-down approaches agree in the prioritization of evacuation as the primary strategy for disaster management. The implementation of this strategy differs significantly, however.

Thus, in the case of Merapi, households learned to coexist with lahar risk by evacuating at the right time and staying away from the volcano, as soon as the eruption begins; this is reinforced by policies such as the "Sister Villages". In Latacunga's case, adaptation is more difficult as households are not accustomed to lahars due to the long cycle and came to believe they might not occur again. However, the 2015 eruption and the change in land management policy made the people take the risk more seriously and consider evacuation options in case of a more significant eruption. The Ecuadorian case based its risks management strategy without any technical solution, such as the Sabo Dam in the Indonesian case.

Both case studies highlight that households prefer to stay and live with the risk of their volcanoes, rather than moving out of the area to maintain their livelihoods (Ariyanti, 2019; Gaafar, 2019).

\subsection{Integrated water resources management and lahars in the case studies}

The river basin organization in the Indonesian case plays the leading role in managing lahar, while the Ecuadorian does not have an equal actor for the pre-eruption phase. The disaster management agencies in Indonesia played at all levels during eruption onset, from national, regional, and local levels, especially in the evacuation. Meanwhile, the local government was the main actor in the pre and post phases of the Ecuadorian case. However, support is provided by risk management agencies that begin from consultancy to complete taking over by the COE during the onset phase. The Indonesian case faced challenges in managing the river basin post-eruption with sand mining activities in the rivers and surrounding areas. Nevertheless, while sand mining exists around Cotopaxi, Latacunga does not face this challenge, as no protection structures currently exist. These differences and similarities are significant in determining what strategies and actors are needed for which phase.

Therefore, based on these experiences, the future of volcanic river basin management (VRBM) linking IWRM and LRM can be summarized as follows (Fig. 11):

The IWRM proposed the three main aspects of water management, in which each relates to the phases of the eruption. The links to LRM are found between the pre-eruption phase and the post-eruption phase of LRM with conservation also utilization in IWRM. Meanwhile, the onset phase links only to the hazards control aspect of the IWRM. Furthermore, within the IWRM and LRM, similarly, we found top-down and bottom-up approaches, which more effectively met during onset eruption rather than the pre and post-eruption phases. Aside from that, the current urban planning approaches address the lahar with risk management but lack consideration of the post-eruption effect with the abundance of materials into lahar resources management.

In an urban context, the IWRM implies city planners' importance to coordinate and collaborate across sectors and administrative boundaries, defining specific and achievable land-uses, especially on up-middown stream basin context. The LRM also nudges the specificity of role sharing of different sectors and cross-boundaries collaboration. The cities in urbanized volcanic river basin settings collaborate better when they understand their role based on their environmental function given by their location.

\section{Conclusions}

Over time, volcanoes have been surrounded by fear, faith, and fascination. It is not much that humans can do to change the dynamic of a volcano; yet, the urban changes that come from intensive alteration on watersheds can significantly increase the impacts of lahars and other volcanic risks.

The occupation of water pathways and the impact on physical land in volcanic river basins put the management of lahar risk at the trajectory of managing land, water, and disaster risk. While the land is managed within the urban planning context, integrated water resource management (IWRM) has since the early nineties been used as a holistic 


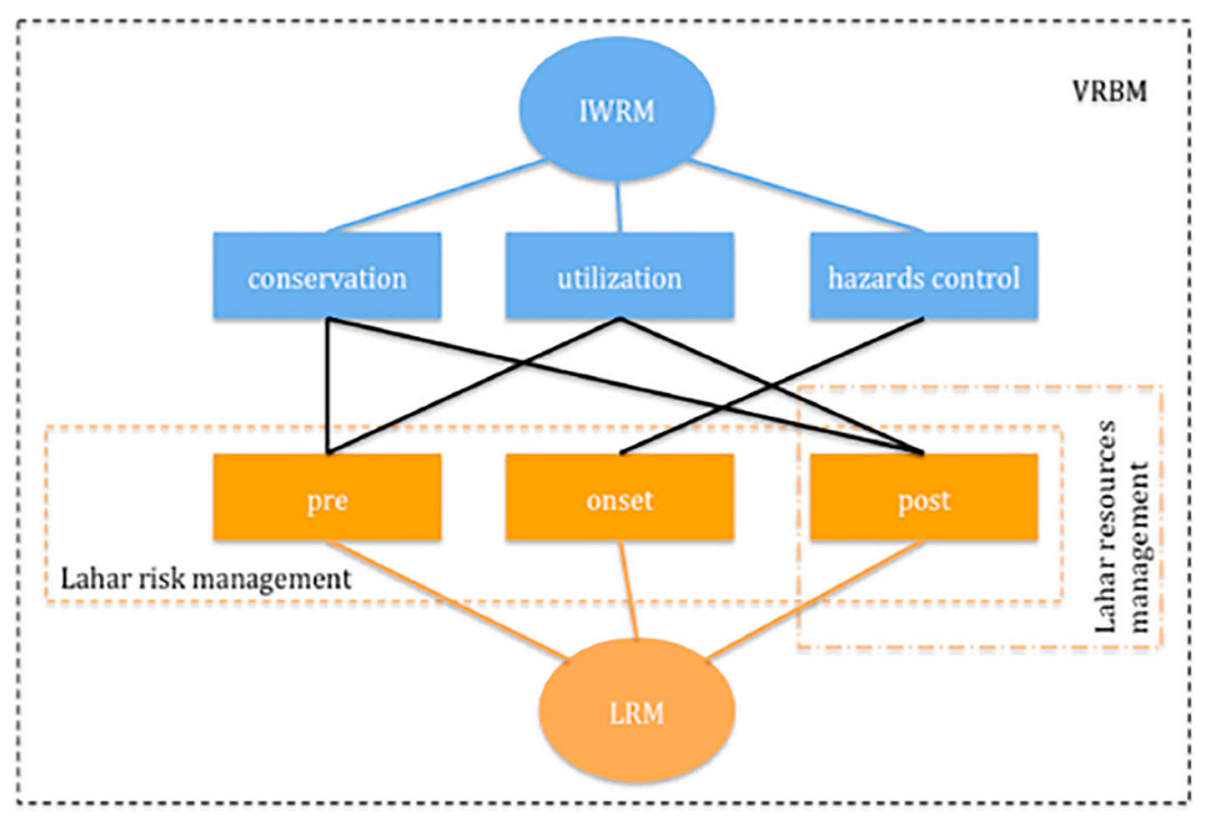

Fig. 11. Volcanic river basin management.

approach to managing water (Mukhtarov, 2008). It has not been urged explicitly as a conjugation for urban planning context until SDG \#11 to make cities and human settlements inclusive, safe, resilient, and sustainable was pronounced in 2015.

Despite the geomorphological risks, cities located near volcanoes are still surprisingly an underdeveloped topic. In these regions, to consider the risks of co-existing with an active volcano are imperative. The case studies illustrate the importance of IWRM implementation to accommodate volcanic risk management and work with communities in building resilience. Both case studies show the active engagement of local communities during and post-disaster, yet the conditions were not as active during pre-disaster.

When developing an IWRM plan, whether or not it is a volcanic river basin should be taken into account and incorporated into the planning. The ways forward of integrating planning between lahar management and water management in an urban setting, and that demand more empirical scholarship to assure livable volcanic cities include:

\section{Policy studies}

More policy studies are needed to manage a volcanic river basin as a conjunction between IWRM and DRR frameworks. Possibilities that relate to strategic planning in countries with volcanoes should be taken into account beyond touristic approaches. Volcanic locations bring environmental qualities and benefits for soil fertility; for instance, periurban governance shall be able to explore better the volcano, not only for its beauty, but also for educational purposes, and disaster risks strategies. Also, the case in Indonesia shows the possibility of 'harvesting' the sand and aggregates from the lahar, which needs further governance structures and institutional frameworks.

\section{Governance aspects}

Governing volcanic river basins is incorporated in many different forms of governance. We need to understand the governance relationships in volcanic river basins and urban planning. The more traditional form that volcanoes have been managed is through disaster risk management defined as high-risk areas that require preservation and conservation and limited access. Consideration should be given to alternative uses of land in conservation areas, such as national parks.
However, in this paper, we propose taking a network governance approach that incorporates the intertwining governance structures, including IWRM +, land governance, and physical planning. This condition needs a paradigm shift to incorporate better both the benefits and risks of volcanic river basins. Focusing on risk management helps in mitigating disaster risk. However, there was a longer interval time of regular volcanic activity than eruption onset conditions, making it more sensible to take into account the benefit of living with volcanoes and the lahar sedimentation as resources.

\section{Integrated approach}

There is a need to walk towards an integrated environmental approach that takes into account how hazards are formed and how they integrate. Multiple layers of jurisdiction and stakeholders created the current messy overlaps between environmental management and policymakers' decisions. These overlaps are taking place in the authority of each stakeholder, where a river basin is managed by different actors of the municipal, regional, and national government; Yet at the same time also managed by non-governmental actors.

However, examples of these two volcanic river basins show when eruptions took place, a sudden integration of stakeholders occurred. Nevertheless, this integration is not long-term. It is necessary to understand the multiple layers and the roles of actors in each layer to achieve better volcanic river basin management.

An integrated strategy includes adapting current planning into the three phases of the eruption (pre, onset, and post) and deciding which phase the current condition is. Designating, which actor plays a role in which phase and the collaboration of top-down and bottom-up approaches could guarantee a better chance of success. Delineating hazard zones for the eruption onset phase is needed for evacuation. The next step is determining when reconstruction and rehabilitation activities can be done for the post-eruption phase, and which activities may resume normal activity in the pre-eruption phase, until the next eruption.

\section{CRediT statements by authors}

Conceptualization, Vicky Ariyanti.

Methodology, Vicky Ariyanti, Tasneim Gaafar, Jurian Edelenbos.

Software, Vicky Ariyanti, Tasneim Gaafar.

Validation, Vicky Ariyanti, Tasneim Gaafar. 
Formal analysis, Vicky Ariyanti, Tasneim Gaafar.

Investigation, Vicky Ariyanti, Tasneim Gaafar.

Resources, Jurian Edelenbos, Peter Scholten, Safira De La Sala.

Data Curation, Vicky Ariyanti, Tasneim Gaafar, Jurian Edelenbos,

Peter Scholten, Safira De La Sala.

Writing - Original Draft, Vicky Ariyanti, Tasneim Gaafar.

Writing - Review \& Editing, Tasneim Gaafar, Safira De La Sala.

Visualization, Vicky Ariyanti, Tasneim Gaafar.

Supervision, Jurian Edelenbos.

Project administration, Vicky Ariynati.

Funding acquisition, Vicky Ariyanti, Tasneim Gaafar.

\section{Declaration of Competing Interest}

The authors declare that they have no known competing financial interests or personal relationships that could have appeared to influence the work reported in this paper.

\section{Acknowledgments}

LPDP Indonesia (Indonesia Endowment Fund for Education). OKP (Orange Knowledge Program) program by NUFFIC (The Dutch organisation for internationalisation in education). Institute for Housing and Urban Development Studies (IHS), Erasmus University Rotterdam.

\section{References}

Ahrens, J., \& Rudolph, P. M. (2006). The importance of governance in risk reduction and disaster management. Journal of Contingencies and Crisis Management, 14(4), 207-220.

Alterman, R. (2011). Guest editorial: comparative research at the frontier of planning law: The case of compensation rights for land use regulations. International Journal of Law in the Built Environment, 3(2), 100-112 2011.

Ariyanti, V. (2019). Governing a volcanic river basin: A culture-sensitive inquiry into the current water resources management practices of Opak Sub-Basin. Indonesia: Erasmus University Rotterdam. Retrieved from https://repub.eur.nl/pub/119148.

Asian Development Bank (2016). River basin management planning in Indonesia: Policy and practice. Manilla: Asian Development Bank. Retrieved from https://www.adb.org/ sites/default/files/publication/185758/river-basin-mgt-ino.pdf.

BBWS SO (2011). Draft Rencana Pengelolaan Sumber Daya Air Wilayah Sungai Progo Opak Serang. Indonesia: Yogyakarta.

BBWS SO (2016). Rencana Pengelolaan Sumber Daya air Wilayah Sungai Progo Opak Serang. Yogyakarta: Indonesia.

Bettencourt, L. M. (2013). The origins of scaling in cities. Science, 340(6139), 1438-1441.

BNPB (2015). Rencana Nasional Penanggulangan Bencana (Renas) 2015-2019. Jakarta: BNPB.

Bromley, R. D. (1979). The functions and development of "colonial" towns: Urban change in the central highlands of Ecuador, 1698-1940. Transactions of the Institute of British Geographers, 30-43.

Camus, G., Gourgaud, A., Mossand-Berthommier, P., \& Vincent, P. (2000). Merapi (Central Java, Indonesia): An outline of the structural and magmatological evolution, with a special emphasis to the major pyroclastic events. Journal of Volcanology and Geothermal Research, 100(1), 139-163.

Cashman, K. V., \& Giordano, G. (2008). Volcanoes and human history. Journal of Volcanology and Geothermal Research, 176(3), 325-329.

Chanson, H. (2004). Sabo check dams-mountain protection systems in Japan.

Chester, D. K., Dibben, C. J., \& Duncan, A. M. (2002). Volcanic hazard assessment in western Europe. Journal of Volcanology and Geothermal Research, 115(3-4), 411-435.

Crafford, A., \& Venzke, E. (2016). Global Volcanism Program, 2016. Report on Cotopaxi (Ecuador). (41:4). Bulletin of the Global Volcanism Network: Smithsonian Institution.

De Bélizal, E., Lavigne, F., Hadmoko, D. S., Degeai, J., et al. (2013). Rain-triggered lahars following the 2010 eruption of Merapi volcano, Indonesia: A major risk. Journal of Volcanology and Geothermal Research, 261, 330-347.

Delcamp, A., Roberti, G., \& de Vries, B. W.v. (2016). Water in volcanoes: evolution, storage and rapid release during landslides. Bulletin of Volcanology, 78(12), 87.

DGWR, \& Yachiyo Engineering Co. Ltd (2001). Consulting services for Mt. Merapi and Mt. Semeru Volcanic Disaster Countermeasures Project (Phase II) Main: Report for Review Master Plan Study. Jakarta. Min.PWH.

Donovan, A., \& Oppenheimer, C. (2014). Science, policy and place in volcanic disasters: Insights from Montserrat. Environmental Science \& Policy, 39, 150-161.

Donovan, K. (2010). Doing social volcanology: Exploring volcanic culture in Indonesia Area, 42(1), 117-126.

Dorava, J. M., \& Meyer, D. F. (1994). Hydrologic hazards in the lower Drift River basin associated with the 1989-1990 eruptions of Redoubt Volcano, Alaska. Journal of Volcanology and Geothermal Research, 62(1-4), 387-407.

Dove, M. R. (2008). Perception of volcanic eruption as agent of change on Merapi volcano, Central Java. Journal of Volcanology and Geothermal Research, 172, 329-337.
Eiser, J. R., Bostrom, A., Burton, I., Johnston, D. M., et al. (2012). Risk interpretation and action: A conceptual framework for responses to natural hazards. International Journal of Disaster Risk Reduction, 1, 5-16.

El Comercio (2015). Concern in Latacunga for empty houses. Retrieved from https:// www.elcomercio.com/actualidad/preocupacion-latacunga-casas-vacias-cotopaxi. html.

Engerman, S. L., \& Sokoloff, K. L. (2002). Factor endowments, inequality, and paths of development among New World economics.

Favereau, M., Robledo, L. F., \& Bull, M. T. (2018). Analysis of risk assessment factors of individuals in volcanic hazards: Review of the last decade. Journal of Volcanology and Geothermal Research, 365, 57-64.

Friese, S. (2019). Qualitative data analysis with ATLAS. ti. SAGE Publications Limited.

Gaafar, T. (2019). Room for the volcano? Shaping the risk management strategies of households in areas prone to lahar risk in. Latacunga - Ecuador: Erasmus University Rotterdam.

Gaillard, J. (2008). Alternative paradigms of volcanic risk perception: The case of Mt Pinatubo in the Philippines. Journal of Volcanology and Geothermal Research, 172(3), $315-328$.

Gleick, P. H. (2003). Global freshwater resources: soft-path solutions for the 21st century. Science, 302(5650), 1524-1528 United States.

Global Water Partnership (2000). Integrated water resources management. TAC background paper no.4, Stockholm, Swedia: Global Water Partnership. Available at http://www.gwp.org/Global/ToolBox/Publications/Background\%20papers/04\% 20Integrated\%20Water\%20Resources\%20Management\%20(2000)\%20English.pdf.

Graefe, O. (2011). River basins as new environmental regions? The depolitization of water management. Procedia-Social and Behavioral Sciences, 14, 24-27 Elsevier.

Hwang, S. (2008). Utilizing qualitative data analysis software: A review of Atlas. ti. Socia Science Computer Review, 26(4), 519-527.

Jaspers, F. G. W. (2003). Institutional arrangements for integrated river basin management. Water Policy, 5(1), 77-90.

JICA (1976). Plan of operation of the master plan study for land erosion and volcanic debris control in the area of Mt. JICA: Merapi in the Republic of Indonesia. Retrieved from http://open_jicareport.jica.go.jp/617/617_108.html.

Kelman, I., \& Mather, T. A. (2008). Living with volcanoes: The sustainable livelihoods approach for volcano-related opportunities. Journal of Volcanology and Geothermal Research, 172(3-4), 189-198.

Keys, H. J., \& Green, P. M. (2008). Ruapehu lahar New Zealand 18 March 2007: Lessons for hazard assessment and risk mitigation 1995-2007. Journal of Disaster Research 3(4), 284-296

La Hora, 10/2016. Ecuador: el tercer país con más volcanes del mundo. Retrieved from https://lahora.com.ec/noticia/1101991837/ecuador-el-tercer-pas-con-ms-volcanesdel-mundo.

Lavigne, F., \& Thouret, J. (2003). Sediment transportation and deposition by rain-triggered lahars at Merapi Volcano, Central Java, Indonesia. Geomorphology, 49(1), 45-69.

Major, J. J., Pierson, T., Dinehart, R., \& Costa, J. (2000). Sediment yield following severe volcanic disturbance-A two-decade perspective from mount St. Helens. Geology, 28(9), 819-822.

Mardiasmo, D., \& Barnes, P. H. (Eds.). (2010). Community response to disasters in Indonesia: Gotong Royong; a double edged-sword. Proceedings of the 9th annual international conference of the international institute for infrastructure renewal and reconstruction. Brisbane, Australia, 2010 (pp. 301-307). Brisbane, Australia: Queensland University of Technology. Retrieved from http://eprints.qut.edu.au/61482/.

Marso, J. N.. Lahars and their effects. (2013). Available at: http://volcanoes.usgs.gov/ hazards/lahar/ [Accessed 2015].

Medema, W., McIntosh, B. S., \& Jeffrey, P. J. (2008). From premise to practice: a critical assessment of integrated water resources management and adaptive management approaches in the water sector. Ecology and Society, 13(2), 29.

Mitchell, D., Enemark, S., \& Van der Molen, P. (2015). Climate resilient urban development: Why responsible land governance is important. Land Use Policy, 48, 190-198.

Molle, F. (2009). River-basin planning and management: the social life of a concept Geoforum, 40(3), 484-494.

Mothes, P. A., Ruiz, M. C., Viracucha, E. G., Ramón, P. A., Hernández, S., Hidalgo, S., Bernard, B., ... Espín, P. A. (2017). Geophysical footprints of Cotopaxi's unrest and minor eruptions in 2015: an opportunity to test scientific and community preparedness. Geophysical footprints of Cotopaxi's unrest and minor eruptions in 2015: an opportunity to test scientific and community preparedness. 2017. Volcanic Unrest. Springer241-270.

Mothes, P. A., \& Vallance, J. W. (2015). Lahars at Cotopaxi and Tungurahua Volcanoes, Ecuador: Highlights from stratigraphy and observational records and related downstream hazards. Lahars at Cotopaxi and Tungurahua Volcanoes, Ecuador: Highlights from stratigraphy and observational records and related downstream hazards. 2015. Volcanic Hazards, Risks and Disasters. 141-168. Elsevier.

Muhr, T. (1991). ATLAS/ti-A prototype for the support of text interpretation. Qualitative Sociology, 14(4), 349-371.

Mukhtarov, F. G. (2008). Intellectual history and current status of Integrated Water Resources Management: A global perspective. Intellectual history and current status of Integrated Water Resources Management: A global perspective. 2008. Adaptive and integrated water management. Springer167-185.

Ndirangu, W., Kabubi, J., \& Dulo, S. (2009). United Nations Development Programme (UNDP), Nile Integrated Water Resources Management (IWRM) Net, United Nation International Strategy for Disaster Reduction (UNISDR). Pretoria, South Africa: United Nations Office for Coordination of Humanitarian Affairs (UNOCHA).

Newhall, C. G., Bronto, S., Alloway, B., Banks, N. G., et al. (2000). 10,000 Years of explosive eruptions of Merapi Volcano, Central Java: archaeological and modern implications. Journal of Volcanology and Geothermal Research, 9-50. Available at http:// www.sciencedirect.com/science/article/pii/S0377027300001323\#, Accessed date: 
1 July 2015 .

Norris, F. H., Stevens, S. P., Pfefferbaum, B., Wyche, K. F., et al. (2008). Community resilience as a metaphor, theory, set of capacities, and strategy for disaster readiness. American Journal of Community Psychology, 41(1-2), 127-150.

Parry, M. L., Canziani, O. F., Palutikof, J. P., Linden, P. J., et al. (2007). Climate change 2007: Impacts, adaptation and vulnerability. Working Group II, Cambridge, United Kingdom and New York, NY, USA: Cambridge University Press. Retrieved from https://www.ipcc.ch/report/ar4/wg2/.

Pierson, T. C., Wood, N. J., \& Driedger, C. L. (2014). Reducing risk from lahar hazards: Concepts, case studies, and roles for scientists. Journal of Applied Volcanology, 3(1), $1-25$.

Provinsi, B. P. S., \& Yogyakarta, D. I. (2018). Jumlah Penduduk menurut Kabupaten/Kota di D.I. Yogyakarta (Jiwa).. Retrieved from https://yogyakarta.bps.go.id/ dynamictable/2017/08/02/32/jumlah-penduduk-menurut-kabupaten-kota-di-d-iyogyakarta-jiwa-.html Accessed 2018 .

Rijke, J., van Herk, S., Zevenbergen, C., \& Ashley, R. (2012). Room for the River: Delivering integrated river basin management in the Netherlands. International Journal of River Basin Management, 10(4), 369-382.

Rodolfo, K. S. (1991). Rain-lahar generation and sediment delivery systems at Mayon Volcano, Philippines. Sedimentation in volcanic setting. society for sedimentary geology (SEPM), SEPM Special Publication No.45. Retrieved from http://archives. datapages.com/data/sepm_sp/SP45/Rain_Lahar_Generation_and_Sediment.htm.

Sagala, S., Okada, N., \& Paton, D. (2009). Predictors of intention to prepare for volcanic risks in Mt Merapi, Indonesia. Journal of Pacific Rim Psychology, 3(2), 47-54.

Savenije, H. H. G., \& Zaag, P. V. D. (2008). Integrated water resources management: Concepts and issues. Physics and Chemistry of the Earth, Parts A/B/C. Elsevier, 33(5), 290-297.

Schlehe, J. (1996). Reinterpretations of mystical traditions. Explanations of a volcanic eruption in Java. Anthropos, 391-409.

Secretaría de Gestión de Riesgos (2017). Manual del Comité de Operaciones de Emergencia. Samborondon Oficina Quito, Ecuador: Centro Integrado de Seguridad. Available at https://www.gestionderiesgos.gob.ec/.

Solanes, M., \& Gonzales-Villarreal, F. (1999). The dublin principles for water as reflected in a comparative assessment of institutional and legal arrangements for integrated water resources management. (GWP's version on origin of IWRM; TAC background paper no. 3), Stockholm: Global Water Partnership/Swedish International. Available at http://www.gwp.org/Global/ToolBox/Publications/Background\%20papers/03\% 20The $\% 20$ Dublin $\% 20$ Principles $\% 20$ for $\% 20$ Water $\% 20$ as $\% 20$ reflected $\% 20$ in $\% 20$ a \%20Comparatice\%20Assessment $\% 20$ of\%20Institutional\%20and\%20Legal \%20Arrangements\%20for\%20IWRM\%20(1999).pdf, Accessed date: August 2014.

Stone, J., Barclay, J., Simmons, P., Cole, P. D., et al. (2014). Risk reduction through community-based monitoring: The vigías of Tungurahua, Ecuador. Journal of Applied Volcanology, 3(1), 1-14.

Thouret, J., Enjolras, G., Martelli, K., Santoni, O., et al. (2013). Combining criteria for delineating lahar-and flash-flood-prone hazard and risk zones for the city of Arequipa, Peru. Natural Hazards \& Earth System Sciences, 13(2).

Toulkeridis, T., Jacome, A., \& Mato, F. (2018). Ethics, policy, and risk assessment of the cotopaxi volcanic crisis in ecuador-Vulnerable society versus unprepared volcanic monitoring staff and authorities. ethics, policy, and risk assessment of the cotopaxi volcanic crisis in Ecuador -Vulnerable society versus unprepared volcanic monitoring staff and authorities. 2018. Geoethics in Latin America. Springer153-170.

Trenberth, K. E., \& Dai, A. (2007). Effects of mount Pinatubo volcanic eruption on the hydrological cycle as an analog of geoengineering. Geophysical Research Letters, 34(15).

UNISDR (2015). Sendai framework for disaster risk reduction 2015-2030. Geneva, Switzerland: UNISDR. Retrieved from https://www.preventionweb.net/files/43291 sendaiframeworkfordrren.pdf.

Vallance, J. (2000). Lahars. Lahars. 2000. Encyclopedia of volcanoes.

van Hofwegen, P., \& Jaspers, F. (1999). Analytical Framework for Integrated Water Resources Management, IHE Monograph 2. Balkema, Rotterdam: Inter-American Development Bank.

Viviroli, D., Archer, D., Buytaert, W., Fowler, H., et al. (2011). Climate change and mountain water resources: Overview and recommendations for research, management and policy. Hydrology and Earth System Sciences, 15(2), 471-504.

White, G. F. (1963). Contributions of geographical analysis to river basin development. Geographical Journal, 412-432 JSTOR.

Widayani, S., et al., 2011. Dampak Letusan Gunung Merapi Mencapai 3,56 Trilyun. Gema BNPB, Ketangguhan Bangsa Dalam Menghadapi Bencana, 2 (No.1), pp. 17-20 Retrieved from http://bnpb.go.id/uploads/migration/pubs/382.pdf [Accessed July 2015].

Wilkinson, E. (2013). Disaster risk governance in volcanic areas-A concept note from Work Package 4 of the Strengthening Resilience in Volcanic areas (STEVA) programme. London: Overseas Development Institute.

Wisner, B., Blaikie, P., Cannon, T., \& Davis, I. (2004). At risk: natural hazards, peoples vulnerability and disasters. New York: Routledge.

Wood, N., \& Soulard, C. (2009). Variations in population exposure and sensitivity to lahar hazards from Mount Rainier, Washington. Journal of Volcanology and Geothermal Research, 188(4), 367-378.

Yusuf, A. A., \& Francisco, H. (2009). Climate change vulnerability mapping for Southeast Asia. Economy and Environment Program for Southeast Asia (EEPSEA), Singapore. 10-15. 